\title{
ACHIEVING NATIONALLY DETERMINED CONTRIBUTIONS THROUGH MARKET MECHANISMS IN ASIA AND THE PACIFIC
}

Bayarmaa Amarjargal, Hannah Ebro, Johan Nylander, and Virender Kumar Duggal

NO. 64

February 2020
ADB SUSTAINABLE DEVELOPMENT WORKING PAPER SERIES 


\section{ADB Sustainable Development Working Paper Series}

\section{Achieving Nationally Determined Contributions through Market Mechanisms in Asia and the Pacific}

Bayarmaa Amarjargal, Hannah Ebro, Johan Nylander, and Virender Kumar Duggal

No. 64 | February 2020
Bayarmaa Amarjargal is a young professional working at the Asian Development Bank (ADB) in its Sustainable Development and Climate Change Department. She has experience working on climate mitigation projects under the Clean Development Mechanism and the Green Climate Fund.

Hannah Ebro is a researcher working as consultant in ADB's Sustainable Development and Climate Change Department. She has experience working on technical assistance projects focused on energy efficiency and climate change.

Johan Nylander is carbon market expert working as consultant in ADB's Sustainable Development and Climate Change Department. His areas of expertise include climate policy, climate finance, and market-based instruments, including international approaches such as Article 6 of the Paris Agreement.

Virender Kumar Duggal is a principal climate change specialist leading ADB's Carbon Market Program under the Sustainable Development and Climate Change Department. He has expertise in the areas of climate change, carbon finance, and trust fund management. 
(c) 2020 Asian Development Bank 6 ADB Avenue, Mandaluyong City, 1550 Metro Manila, Philippines

Tel +632 8632 4444; Fax +63286362444

www.adb.org

Some rights reserved. Published in 2020.

Publication Stock No. WPS200088-2

DOI: http://dx.doi.org/10.22617/WPS200088-2

The views expressed in this publication are those of the authors and do not necessarily reflect the views and policies of the Asian Development Bank (ADB) or its Board of Governors or the governments they represent.

ADB does not guarantee the accuracy of the data included in this publication and accepts no responsibility for any consequence of their use. The mention of specific companies or products of manufacturers does not imply that they are endorsed or recommended by ADB in preference to others of a similar nature that are not mentioned.

By making any designation of or reference to a particular territory or geographic area, or by using the term "country" in this document, $\mathrm{ADB}$ does not intend to make any judgments as to the legal or other status of any territory or area.

This work is available under the Creative Commons Attribution 3.0 IGO license (CC BY 3.0 IGO) https://creativecommons.org/licenses/by/3.0/igo/. By using the content of this publication, you agree to be bound by the terms of this license. For attribution, translations, adaptations, and permissions, please read the provisions and terms of use at https://www.adb.org/terms-use\#openaccess.

This CC license does not apply to non-ADB copyright materials in this publication. If the material is attributed to another source, please contact the copyright owner or publisher of that source for permission to reproduce it. $A D B$ cannot be held liable for any claims that arise as a result of your use of the material.

Please contact pubsmarketing@adb.org if you have questions or comments with respect to content, or if you wish to obtain copyright permission for your intended use that does not fall within these terms, or for permission to use the ADB logo.

The ADB Sustainable Development Working Paper Series presents data, information, and/or findings from ongoing research and studies to encourage exchange of ideas and elicit comment and feedback about development issues in Asia and the Pacific. Since papers in this series are intended for quick and easy dissemination, the content may or may not be fully edited and may later be modified for final publication.

Corrigenda to ADB publications may be found at http://www.adb.org/publications/corrigenda.

Notes:

In this publication, "\$” refers to United States dollars.

ADB recognizes "China" as the "People's Republic of China" and "Vietnam" as "Viet Nam." 


\section{CONTENTS}

TABLES, FIGURES, AND BOX iv

ACKNOWLEDGMENTS $\quad$ v

EXECUTIVE SUMMARY i vi

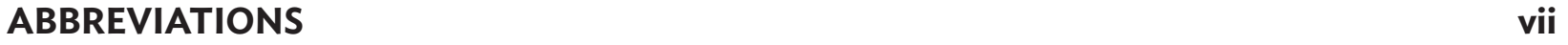

1 INTRODUCTION 1

1.1 The Paris Agreement and Nationally Determined Contributions 1

1.2 The Emissions Gap $\quad 1$

1.3 Article 6 of the Paris Agreement 3

1.4 Scope, Purpose, and Limitations of this Working Paper 4

2 INTEREST IN MARKET MECHANISMS FOR ACCOMPLISHING NATIONALLY 7 DETERMINED CONTRIBUTIONS

2.1 Global Context $\quad 8$

2.2 Regional Context 9

3 LINKING NATIONALLY DETERMINED CONTRIBUTION TARGETS WITH MARKET 15 MECHANISMS

3.1 Countries with Unconditional and Conditional Targets in Nationally Determined 15 Contributions

3.2 Countries with Conditional Targets in Nationally Determined Contributions 18

3.3 Countries with Unconditional Targets in Nationally Determined Contributions 19

3.4 Countries with Sector Policy Targets in Nationally Determined Contributions 19

4 COUNTRY EXPERIENCE WITH MARKET MECHANISMS 20

4.1 Experience with Project-Based Mechanisms $\quad 20$

4.2 Experience with Nationally Appropriate Mitigation Actions 21

4.3 Preparedness for a New Generation of Carbon Market Mechanisms 22

5 CONCLUSION

APPENDIX

1 National and Sectoral Targets of the Developing Members of ADB that are Considering or Intending to Use Market Mechanisms to Accomplish their Nationally Determined Contributions

2 Overview of Emissions Trading Systems of ADB's Developing Members 41

3 Experience with Project-Based Mechanisms of ADB's Developing Members 43

4 Experience with Transparency and Reporting of Emission Reductions 44

$\begin{array}{ll}\text { REFERENCES } & 46\end{array}$ 


\section{TABLES, FIGURES, AND BOX}

\section{Tables}

1 Planned Use of Market Mechanisms

2 Intention to Use Market Mechanisms Based on Statements in the Nationally Determined Contributions 9

3 Statements on the Use of Market Mechanisms in Nationally Determined Contributions 12

4 Conditional Reduction Targets of Group 1 Countries 16

5 Experience with Project-Based Mechanisms among Group 1Countries 20

6 Progress of Nationally Appropriate Mitigation Actions in India, Indonesia, and Thailand 22

7 Examples of International Initiatives that Support Country Preparations for Post-2020 Carbon Markets

8 Preparedness of Group 1 Countries for Post-2020 Carbon Markets

\section{Figures}

1 Global Greenhouse Gas Emissions under Different Scenarios and Emissions Gap by 2030 and 2050

2 Expression of Intent to Use Market Mechanisms According to Submitted Nationally

Determined Contributions

3 Share of ADB's Developing Members in Global and Regional Greenhouse Gas Emissions, 201810

4 Overview of Conditionality of Economy-Wide Targets in Group 1 Developing Member Countries

\section{Box}

Definitions 


\section{ACKNOWLEDGMENTS}

This working paper was prepared by Bayarmaa Amarjargal, Hannah Ebro, Johan Nylander, and Virender Kumar Duggal with the help of a team of experts under the Article 6 Support Facility of the Asian Development Bank (ADB). The Article 6 Support Facility is part of the Carbon Market Program within ADB's Sustainable Development and Climate Change Department.

The preparation of this paper also benefited from expert advice from, and peer review by Esmyra P. Javier, Janet Arlene Amponin, Bradley Todd Hiller, Takeshi Miyata, and Kate Hughes from ADB and Kentaro Takahashi from the Institute for Global Environmental Strategies. Their contributions are greatly appreciated, as are the dedicated efforts of Joane Corbe, Ghia Villareal, Anna Liza Guimong Cinco, Cherille Miranda, and Mari-Jo Rea to see this publication project through to its timely completion. Authors also acknowledge contributions from Edith Creus for layout and typesetting, Layla Amar for copy-editing as well as Levi Lusterio and Joel Pinaroc for proofreading. 


\section{EXECUTIVE SUMMARY}

The Paris Agreement, adopted in 2015 by the Parties to the United Nations Framework Convention on Climate Change (UNFCCC), sets out long-term goals to strengthen the global response to address the challenges of climate change. It establishes a global framework for avoiding the negative effects of climate change by limiting global warming to well below 2 degrees Celsius $\left({ }^{\circ} \mathrm{C}\right.$ ) and, if possible, below $1.5^{\circ} \mathrm{C}$. To reach this goal, the Paris Agreement requires the signatory Parties to outline and communicate their climate action targets and commitments, known as nationally determined contributions (NDCs).

The NDCs are at the heart of the Paris Agreement and are expected to be implemented from 2020 to 2030. They convey the countries' efforts on climate change mitigation and adaptation commitments. All Parties to the UNFCCC are requested to submit the next round of NDCs (new or updated NDCs) by 2020 and subsequent rounds every 5 years thereafter, regardless of their individual implementation time frames. Each submission of NDCs is expected to be more ambitious in terms of climate targets and actions compared to the previous submissions to represent a progression in the level of ambitions over time.

The collective level of ambition in the first round of NDCs is insufficient to limit the global warming below $2^{\circ} \mathrm{C}$ and countries will have to raise their climate targets in the next round of NDCs, to meet the goals of the Paris Agreement. One way to do this is to implement Article 6 of the Paris Agreement, which sets a new framework for the use of market-based and nonmarket-based international cooperative approaches intended as an instrument for ambition raising and supporting sustainable development. For example, Article 6 can help in establishing a policy foundation for linking emissions trading systems with international market mechanisms, leading to a price on carbon. Although its modalities, rules, and guidelines still have to be agreed on, Article 6 provides a foundation for post-2020 carbon markets at the regional and international levels.

This working paper aims to analyze the NDCs of 41 developing member countries (DMCs) of the Asian Development Bank (ADB) in Asia and the Pacific especially in the context of their intent and preparedness to use market mechanisms in achieving targets set out in their NDCs and potentially raising ambition over time. This review of the NDCs of ADB's DMCs shows that there are 20 countries that are intending or considering to use market mechanisms (categorized as Group 1), 16 countries that have not stated their positions on the use of market mechanisms in their NDCs (Group 2) and 5 countries that mentioned that they will not use market mechanisms (Group 3). This working paper focuses on Group 1 DMCs that have relatively explicit intentions or considerations of using market mechanisms to accomplish their NDC commitments and analyzes their experience and preparedness in using market mechanisms which can potentially be relevant for Article 6 of the Paris Agreement.

Section 1 describes the role of NDCs, Article 6, and market mechanisms as well as purpose, scope and limitations of the paper. Section 2 covers a general review of interest in market mechanisms at the international level and in Asia and the Pacific, then focuses on the 20 ADB's DMCs that forms Group 1 for the rest of the paper. Section 3 analyzes the conditionality of the NDC mitigation targets and their possible links with market mechanisms. Section 4 gives an overview of experience with market mechanisms and ongoing activities in preparation for post-2020 markets. Section 5 summarizes key findings of the analyses. 


\section{ABBREVIATIONS}

\begin{tabular}{|c|c|}
\hline ADB & Asian Development Bank \\
\hline BAU & business-as-usual \\
\hline CDM & Clean Development Mechanism \\
\hline $\mathrm{Cl}-\mathrm{ACA}$ & Collaborative Instruments for Ambitious Climate Action \\
\hline COP & Conference of the Parties \\
\hline DMC & developing member country \\
\hline ETS & emissions trading system/scheme \\
\hline FCPF & Forest Carbon Partnership Facility \\
\hline GHG & greenhouse gas \\
\hline $\mathrm{GtCO}_{2} \mathrm{e}$ & gigatons (metric) of carbon dioxide equivalent \\
\hline ICAP & International Carbon Action Partnership \\
\hline IGES & Institute for Global Environmental Strategies \\
\hline INDC & intended nationally determined contribution \\
\hline ITMO & internationally transferred mitigation outcome \\
\hline JCM & Joint Crediting Mechanism \\
\hline Lao PDR & Lao People's Democratic Republic \\
\hline $\mathrm{MBI}$ & market-based instrument \\
\hline MRV & measurement, reporting, and verification \\
\hline NAMA & nationally appropriate mitigation action \\
\hline NDC & nationally determined contribution \\
\hline PMR & Partnership for Market Readiness \\
\hline PRC & People's Republic of China \\
\hline REDD+ & $\begin{array}{l}\text { reducing emissions from deforestation and forest degradation, plus the sustainable } \\
\text { management of forests, and the conservation and enhancement of forest carbon stocks } \\
\text { in developing countries }\end{array}$ \\
\hline TCAF & Transformative Carbon Asset Facility \\
\hline UNEP & United Nations Environment Programme \\
\hline UNFCCC & United Nations Framework Convention on Climate Change \\
\hline
\end{tabular}





\section{INTRODUCTION}

\subsection{The Paris Agreement and Nationally Determined Contributions}

The Paris Agreement, adopted by 195 countries in 2015, sets out long-term goals to strengthen the global response to address the challenges of climate change. It brings countries together for a common cause: to set long-term goals to combat climate change. The Paris Agreement thereby charts a new course for global climate action. Its central aim is to strengthen the response to the threat of climate change by keeping the rise in global temperatures in this century well below 2 degrees Celsius $\left({ }^{\circ} \mathrm{C}\right)$ relative to preindustrial levels, while pursuing a target of $1.5^{\circ} \mathrm{C}$. It aims to accelerate and intensify the actions and investments required for a sustainable low-carbon future. As of December 2019, 187 out of 197 Parties to the United Nations Framework Convention on Climate Change (UNFCCC) have ratified the Paris Agreement, including 41 developing member countries (DMCs) supported by the Asian Development Bank (ADB) in Asia and the Pacific. ${ }^{1}$

Under the Paris Agreement, all Parties are required to submit their climate change targets in the form of nationally determined contributions (NDCs) to the UNFCCC and to strengthen their efforts in the years ahead. NDCs are at the heart of the Paris Agreement, setting out national post-2020 climate targets and commitments. These are intended to fortify global climate efforts by encouraging countries to implement actions from 2020 onward, which will thus make the Paris Agreement target of keeping global warming more achievable. The NDCs consist of pledges to mitigate climate change as well as priorities for adaptation and other climate-related actions. Under the Paris Agreement, all Parties must report to the UNFCCC on their national greenhouse gas (GHG) inventory and progress made in implementing NDCs. The NDCs are to be updated every 5 years, and each updated NDC is expected to be more ambitious in terms of climate targets and actions compared to the previous submission to ensure progression in level of ambition over time.

\subsection{The Emissions Gap}

As of December 2019, 184 Parties had submitted their first NDCs while two Parties (Marshall Islands and Suriname) had submitted their second NDCs, according to the UNFCCC's NDC Registry (UNFCCC n.d.d). The impact of the climate ambitions set down in the current NDCs has been projected and assessed on several occasions. In October 2018, the Intergovernmental Panel on Climate Change (IPCC) published its Special Report on Global Warming of $1.5^{\circ} \mathrm{C}$, which stated with "high confidence" that pathways reflecting the mitigation ambitions of the countries "would not limit global warming to $1.5^{\circ} \mathrm{C}$ even if supplemented by very challenging increases in the scale and ambition of emission reductions after 2030" (IPCC 2018).

In November 2019, the United Nations Environment Programme (UNEP) released the 10th edition of its Emissions Gap Report with a clear message: the collective impact of the NDCs falls short of the level needed to reach the Paris goal (UNEP 2019). The UNEP Emissions Gap Report 2019 examined the gap between reduction pledges and the reductions required to achieve the Paris Agreement goal

1 Only 40 of the 41 DMCs of ADB have ratified the Paris Agreement. The Kyrgyz Republic has signed the agreement but has not yet ratified it. 


\section{Figure 1: Global Greenhouse Gas Emissions under Different Scenarios and Emissions Gap by 2030 and 2050}

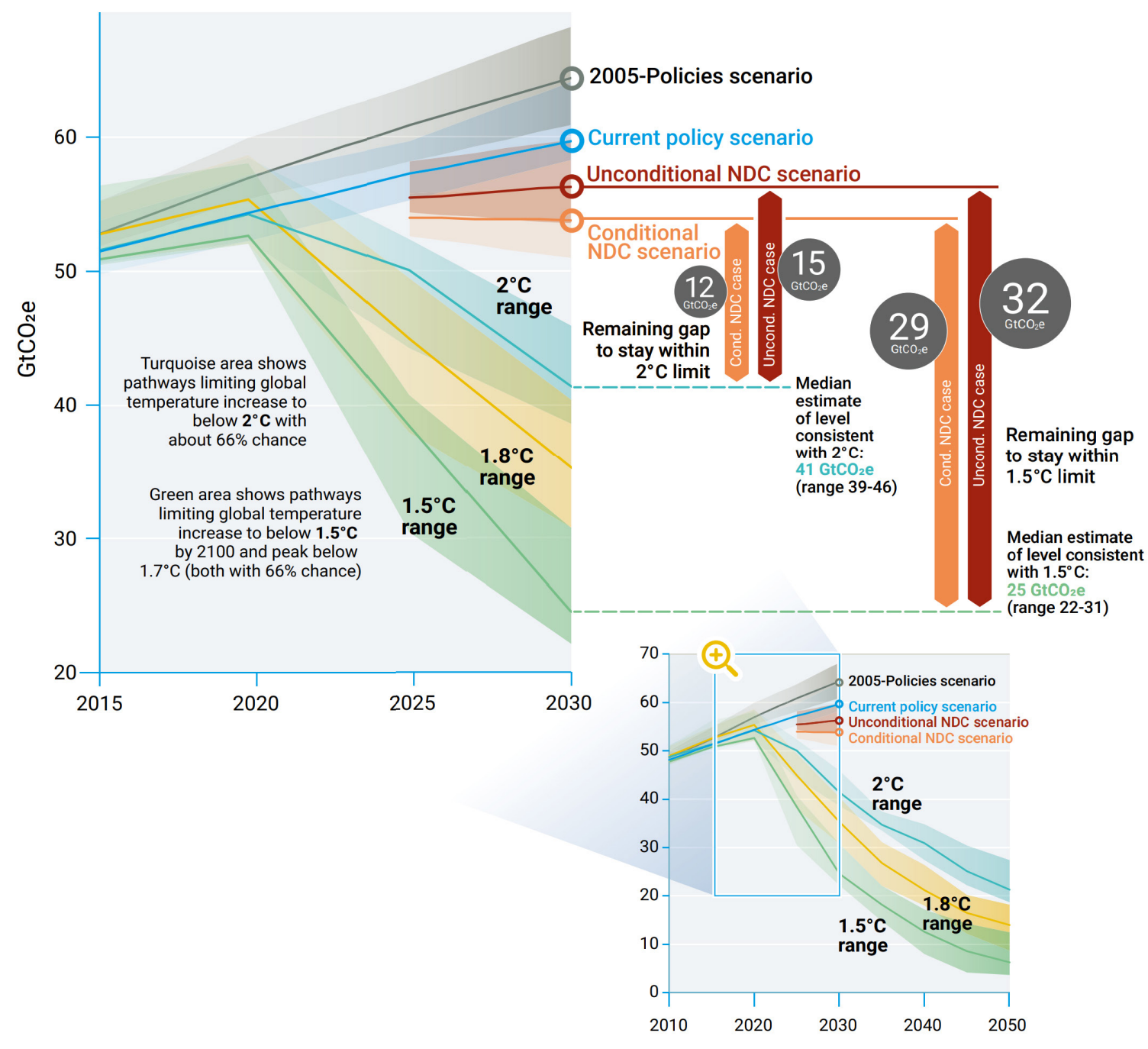

$\mathrm{GtCO}_{2} \mathrm{e}=$ gigatons of carbon dioxide equivalent, $\mathrm{NDC}=$ nationally determined contribution.

Note: Based on median estimate and the 10th and 90th percentile range.

Source: United Nations Environment Programme (UNEP). 2019. Emissions Gap Report 2019.

of limiting warming well below $2^{\circ} \mathrm{C}$ by the end of this century. Considering only the current policies, ${ }^{2}$ global GHG emissions in 2030 are estimated to be 60 gigatons of carbon dioxide equivalent $\left(\mathrm{GtCO}_{2} \mathrm{e}\right)$, in contrast to $41 \mathrm{GtCO}_{2} \mathrm{e}$ being targeted under the Paris Agreement for limiting warming to $2^{\circ} \mathrm{C}$ and $25 \mathrm{GtCO}_{2} \mathrm{e}$ for a $1.5^{\circ} \mathrm{C}$ warming scenario. The report mentioned that even if both the unconditional

2 According to the UNEP Emissions Gap Report 2019, the "current policy scenario projects GHG emissions assuming all currently adopted and implemented policies (defined as legislative decisions, executive orders, or equivalent) are realized and that no additional measures are undertaken." Furthermore, the report defines the "current policy trajectory" as the trajectory that is "based on estimates of 2020 emissions considering projected economic trends and current policy approaches including policies at least through 2015." (Source: United Nations Environment Programme. 2019. Emissions Gap Report 2019.) 
and conditional NDCs of all countries were fully implemented, these will only result in a maximum of 6 $\mathrm{GtCO}_{2}$ e reduction in 2030 compared with the current policy scenario. Even if all NDCs were achieved in full (i.e., even with the full implementation of the unconditional and conditional NDC targets by 2030 and if current climate actions were to proceed consistently until 2100), the gap that the world needs to close remains very large-about $12 \mathrm{GtCO}_{2}$ e gap estimated in 2030 if global warming is to be limited to below $2^{\circ} \mathrm{C}$, or $29 \mathrm{GtCO}_{2}$ e gap if global warming is to be limited to below $1.5^{\circ} \mathrm{C}$ by 2100 . If this gap is not closed, the global temperature by 2100 would be $3.0^{\circ} \mathrm{C}$ - still 1 full degree in excess of the Paris target. Figure 1 shows the projected global GHG emissions by 2030 and 2050 and the gap that must be closed to achieve the $1.5^{\circ} \mathrm{C}$ warming target.

In other words, if countries do not undertake unprecedented and rapid actions soon and do not raise their NDC targets before 2030, the increase in global temperature by the end of the 21st century would most likely exceed $2^{\circ} \mathrm{C}$. The UNEP report further emphasized that countries must increase their NDC ambitions threefold to achieve the $2^{\circ} \mathrm{C}$ goal and fivefold to achieve the $1.5^{\circ} \mathrm{C}$ goal.

\section{"Dramatic strengthening of the NDCs is needed in 2020. Countries must increase their NDC ambitions threefold to achieve the $2^{\circ} \mathrm{C}$ goal and more than fivefold to achieve the $1.5^{\circ} \mathrm{C}$ goal."}

- UNEP Emissions Gap Report 2019

\subsection{Article 6 of the Paris Agreement}

Many scientific reports have shown why it is important to implement NDCs and raise climate ambitions to keep global warming within $1.5^{\circ} \mathrm{C}$ to meet the Paris Agreement goal. The next question is how to achieve this target. International market mechanisms can play an important role in facilitating the implementation of NDCs and in allowing higher mitigation ambitions. The term "market mechanisms" or "market-based approaches" can cover a wide range of instruments that use GHGs, carbon or different units or assets as the market commodity and utilize concepts of price, supply and demand, and other economic variables. Various forms of market mechanisms as well as other mitigation concepts could potentially be linked with new and international market mechanisms, being set under Article 6 of the Paris Agreement.

Article 6 offers an opportunity for countries to implement new approaches to climate change mitigation, including international cooperative approaches. It enables Parties to cooperate voluntarily in achieving their NDCs, and to promote sustainable development and environmental integrity. International market mechanisms under Article 6 could also provide flexibility and contribute to the cost-efficiency of climate mitigation actions since the purchase of international carbon market units could lower the cost of mitigation. The acquiring countries can then adopt more ambitious mitigation targets. This approach means taking advantage of lower-cost mitigation opportunities in the host countries, assuming that marginal abatement costs are lower in the host country (Fuessler et al. 2019).

Article 6 comprises three approaches for cooperation between Parties: "cooperative approaches" under Article 6.2; a new mechanism for promoting mitigation and sustainable development (Articles 6.4-6.7); and a framework for coordination of nonmarket cooperative approaches (Articles 6.8 and 6.9) (ADB 2018b). The market-based approaches in Articles 6.2 and 6.4 set the framework for post-2020 carbon markets, creating opportunities at the regional and international levels and incentivizing mitigation activities by both public and private entities. 
In the cooperative approaches under Articles 6.2-6.3, Parties could opt to meet their NDCs by using internationally transferred mitigation outcomes (ITMOs). ITMOs aim to "provide a basis for facilitating international recognition of cross-border applications of subnational, national, regional, and international carbon pricing initiatives" (World Bank 2019d). The Article 6.2 approach is a bottom-up approach with less centralized regulation where forms of cooperation will be largely agreed bilaterally or multilaterally. In contrast, Article 6.4 is a centralized mechanism under the authority and guidance of the Conference of the Parties (COP) serving as the meeting of the Parties to the Paris Agreement. Article 6.4 establishes a mechanism allowing countries to contribute to GHG emissions mitigation and sustainable development. Both Articles 6.2 and 6.4 are open to all countries and the emissions reductions can be used to meet the NDC of either the host country or another country.

The precise nature of ITMOs and the architecture of the Article 6.4 mechanism are both still being discussed. The operationalization of the new mechanisms under Article 6 is one of the challenges that must be overcome to enable market-based approaches to deliver on its potential for cost-effective decarbonization. Although Parties to the UNFCCC reached agreement on the implementation of the Paris Agreement through the Paris Rulebook in the 24th Conference of the Parties (COP 24), no clear agreement was made regarding Article 6. Issues such as defining ITMOs and metrics, accounting through corresponding adjustments, scope of activities, governance, and other operationalizing provisions under Article 6 were deferred to the 25th Conference of the Parties (COP 25). The negotiations picked up at COP 25, held in December 2019, where Parties came very close to a solution. The Parties managed to agree on basic principles as part of a draft text for Article 6.2: the definition of ITMOs, accounting and corresponding adjustments, reporting, and review, among other aspects. The last version of the draft negotiation text for Article 6.4 more or less contains a full operationalization of the new mechanism under Article 6.4. However, the negotiations fell over how and to what extent units from the Kyoto Protocol could be transitioned into the Paris Agreement period. Moreover, not being able to agree on a mandatory Share of Proceeds for Article 6.2 to mimic the provision for Article 6.4 also contributed to the collapse. Negotiations will continue during 2020 with a view to adopt the guidance, rules, modalities, and procedure for Article 6 at the 26th Conference of the Parties (COP 26) in Glasgow. If the cooperation mechanism under Article 6 can be properly designed, it should help countries achieve their GHG emission reduction targets and raise their climate ambitions.

\subsection{Scope, Purpose, and Limitations of this Working Paper}

This working paper analyzes the NDCs of 41 DMCs of ADB in Asia and the Pacific, and focuses on 20 DMCs in the context of their intent and preparedness to use market mechanisms in achieving targets set out in their NDCs and potentially raising ambition over time. ${ }^{3}$ It analyzes NDC statements on the use of market mechanisms and tries to assess the preparedness of ADB's DMCs for accessing new carbon markets under Article 6 of the Paris Agreement. By citing statements made by countries in their NDCs, this paper aims to emphasize the importance of highlighting the countries' positions in their NDCs as these statements become the main source of understanding countries' positions.

As the rules and guidance for the international carbon market under the Paris Agreement are still being determined, countries have not been able to operationalize market-based approaches under Article 6. However, there are a few examples of already existing international carbon market approaches that may translate into the post-2020 period and there are clear indications of countries wanting to make use of Article 6. To provide an understanding of how this landscape may develop, this paper examines market

3 ADB has 49 regional members consisting of 41 DMCs currently receiving ADB assistance, five developing members that have graduated from regular ADB assistance on the basis of set criteria (Brunei Darussalam; Hong Kong, China; the Republic of Korea; Singapore; and Taipei,China), and 3 developed members (Australia, Japan, and New Zealand) (ADB 2019b). 
mechanisms in a broader sense in relation to NDCs and provides an overview of the experience from the Kyoto Protocol mechanisms that countries can build on as well as an overview of countries' current engagement in various market-based approaches. In other words, while the main focus is international carbon market mechanisms under Article 6 of the Paris Agreement, countries' plans, use of, and experience with domestic carbon market mechanisms as well as noncarbon market mechanisms are used to provide an understanding of the countries' preparedness for and likeliness of engaging in international carbon market mechanisms. Therefore, this paper includes broad areas of national, bilateral, and international market mechanisms including emissions trading systems (ETSs), baseline-and-crediting mechanisms such as the Clean Development Mechanism (CDM) and the Joint Crediting Mechanism (JCM) as well as other types of internationally supported initiatives such as Nationally Appropriate Mitigation Actions (NAMAs). Definitions of terminologies used in the paper are described in below box and their linkages with post-2020 markets are discussed in more detail in Section 4.

\section{Box: Definitions}

Carbon pricing. This is an instrument that "curbs greenhouse gas (GHG) emissions by placing a fee on emitting and/or offering an incentive for emitting less." It can take different forms, but all approaches aim to create a price signal on GHG emissions. Carbon pricing instruments include emissions trading systems (ETS), carbon taxes, offset mechanisms, results-based climate finance and internal carbon prices set by organizations. $^{b}$ The two common types of carbon pricing instruments include ETS and carbon tax. Market mechanisms are one form of carbon pricing, but not all carbon pricing instruments are market-based.

Emissions trading system. ETS is a market-based instrument that can be used to reduce GHG emissions. It "works on the principle of 'cap-and-trade'. The government imposes a limit (cap) on the total emissions in one or more sectors of the economy. Companies in these sectors need to hold one permit for every ton of emissions they release. They may either receive or buy permits and can trade these with other companies." This is the "trade" part of "cap-and-trade".

Clean Development Mechanism. This is a project-based mechanism which "allows emission-reduction projects in developing countries to earn certified emission reduction (CER) credits, each equivalent to one ton of carbon dioxide. These CERs can be traded and sold and used by industrialized countries to meet a part of their emission reduction targets under the Kyoto Protocol."

Joint Crediting Mechanism. This is "a project-based bilateral offset crediting mechanism initiated by the Government of Japan to facilitate the diffusion of low-carbon technologies."e

Nationally Appropriate Mitigation Actions. These refer to "any action that reduces emissions in developing countries and is prepared under the umbrella of a national governmental initiative." They can involve projectbased or policy and program level approaches directed at transformational change within an economic sector, or actions across sectors for a broader national focus.

a United Nations Framework Convention on Climate Change (UNFCCC). n.d.a. About Carbon Pricing. https://unfccc.int/aboutus/regional-collaboration-centres/the-ci-aca-initiative/about-carbon-pricing.

b World Bank n.d. Carbon Pricing Dashboard. https://carbonpricingdashboard.worldbank.org/what-carbon-pricing.

International Carbon Action Partnership (ICAP). 2019. Emissions Trading and Carbon Tax: Two Instruments, One Goal. ETS Brief. https://icapcarbonaction.com/en/?option=com_attach\&task=download\&id=638.

d UNFCCC. n.d.g. What is the clean development mechanism? https://cdm.unfccc.int/about/index.html.

e Asian Development Bank (ADB). 2016. Joint Crediting Mechanism: An Emerging Bilateral Crediting Mechanism. Manila. https:// www.adb.org/documents/jcm-emerging-bilateral-crediting-mechanism.

f UNFCCC. n.d.c. Nationally Appropriate Mitigation Actions (NAMAs). https://unfccc.int/topics/mitigation/workstreams/ nationally-appropriate-mitigation-actions. 
This paper acknowledges that statements in the NDCs may not represent the latest views or positions of governments regarding their intention to use market mechanisms. Countries may have been engaged in various initiatives using market mechanisms or their intentions to use market mechanisms may have changed since the submission of their NDCs. This working paper does not intend to assess all activities carried out by the $41 \mathrm{DMCs}$ that may represent their interest in using market mechanisms. Rather, this paper assesses countries' interest in using market mechanisms as expressed in their NDCs and analyzes a selected number of DMCs that have expressed interest or consideration in their NDCs on using different forms of market mechanisms.

The authors also recognize that statements in the NDCs could be interpreted in different ways, as countries' NDCs are not presented in the same manner, and there are explicit and implicit mentions of different types of market mechanisms. Therefore, this paper is focused on explicit mentions of terms such as "market mechanisms," "crediting mechanisms," "carbon markets," "carbon credits," and "ETSs," while also taking into consideration implicit mentions of market mechanisms in the NDCs. It should also be noted that the paper was based on desktop analysis of publicly available secondary data and did not involve collection of primary data from DMCs or direct consultations with the countries to analyze their intentions on market mechanisms and their preparedness for new market mechanisms.

This working paper is a continuation of Assessing the Intended Nationally Determined Contributions of ADB Developing Members, an ADB knowledge product published in August 2016 that examined DMCs in Asia and the Pacific receiving ADB assistance (excluding graduated developing members) that had submitted their intended nationally determined contributions (INDCs) at the time of publication. The present paper extends on the earlier analysis by focusing on references to market mechanisms in NDC statements. This paper examines all 39 NDCs and the two INDCs of the Kyrgyz Republic and the Philippines. ${ }^{4}$

4 The Kyrgyz Republic has not ratified the Paris Agreement, and the Philippines has not converted its INDC into an NDC; hence, their INDCs were used in the analysis. A country's INDC is converted into an NDC when it formally joins the Paris Agreement by submitting an instrument of ratification, acceptance, approval, or accession, unless the country decides otherwise. 


\section{INTEREST IN MARKET MECHANISMS FOR ACCOMPLISHING NATIONALLY DETERMINED CONTRIBUTIONS}

This section explores the expressed interest of Parties at the international and regional levels, with focus on developing members of the Asian Development Bank (ADB), to indicates possible interest in implementing Article 6 of the Paris Agreement. As of 15 December 2019, 195 out of 197 Parties to the United Nations Framework Convention on Climate Change (UNFCCC) have signed the Paris Agreement, and 187 Parties have ratified the agreement. Out of the 184 Parties that have submitted nationally determined contributions (NDCs), 182 Parties have submitted their first NDCs, and two Parties, the Marshall Islands and Suriname, have already submitted their second NDC according to the UNFCCC NDC Registry. Among 184 Parties that have submitted NDCs, a total of 102 Parties have communicated in their NDCs their intention or consideration of using market mechanisms (IGES 2019b). Figure 2 shows the status of submissions of NDCs to the UNFCCC as well as the number of Parties interested in using market mechanisms in achieving NDCs.

\section{Figure 2: Expression of Intent to Use Market Mechanisms According to Submitted Nationally Determined Contributions at Global Level}

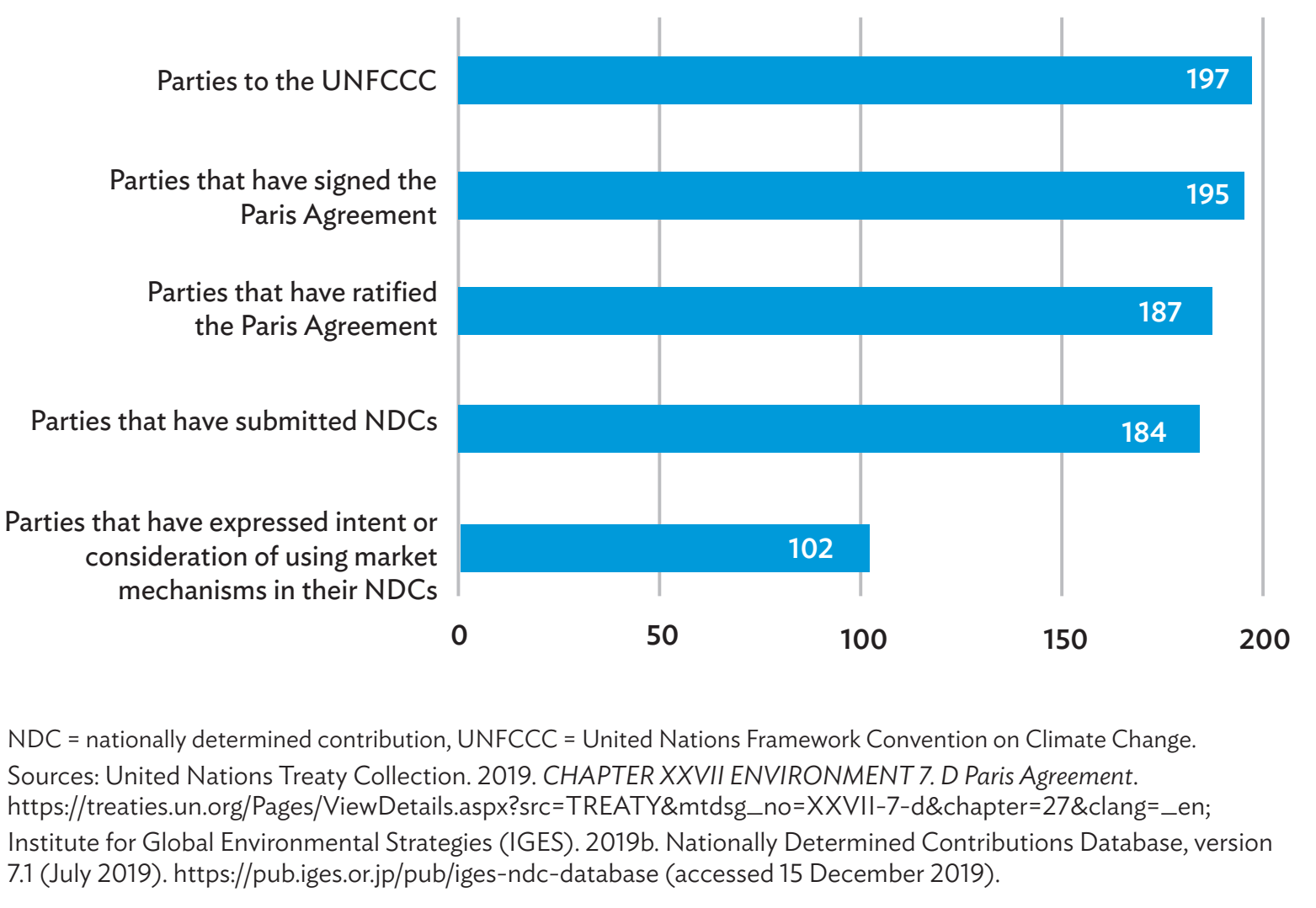




\subsection{Global Context}

The 102 Parties that have mentioned their intention to use market mechanisms in their NDCs accounted for $58.6 \%$ of global emissions in 2015 (IGES 2019b). ${ }^{5}$ Table 1 presents an analysis of UNFCCC Parties' NDCs and their intent to use various types of market mechanisms including national, bilateral, regional and international mechanisms.

Table 1: Planned Use of Market Mechanisms

\begin{tabular}{|c|c|c|c|c|c|c|c|c|c|}
\hline Item & Asia & $\begin{array}{l}\text { North } \\
\text { Africa } \\
\text { and } \\
\text { Middle } \\
\text { East }\end{array}$ & $\begin{array}{c}\text { Sub- } \\
\text { Saharan } \\
\text { Africa }\end{array}$ & $\begin{array}{l}\text { Eastern } \\
\text { Europe } \\
\text { and } \\
\text { Central } \\
\text { Asia }\end{array}$ & Europe & $\begin{array}{l}\text { Latin } \\
\text { America } \\
\text { and the } \\
\text { Caribbean }\end{array}$ & $\begin{array}{l}\text { North } \\
\text { America }\end{array}$ & Oceania & Total \\
\hline \multicolumn{10}{|c|}{ Intention to use market mechanisms mentioned in $\mathrm{NDCs}^{\mathrm{a}}$} \\
\hline Number of Parties & 16 & 8 & 34 & 9 & 6 & 22 & 1 & 6 & 102 \\
\hline \multicolumn{10}{|c|}{ Type of market mechanisms ${ }^{b}$} \\
\hline International & 14 & 7 & 33 & 9 & 4 & 20 & 1 & 6 & 94 \\
\hline Regional & 2 & 1 & 2 & 1 & 3 & 3 & 2 & 2 & 16 \\
\hline Bilateral & 5 & 0 & 0 & 1 & 0 & 4 & 0 & 1 & 11 \\
\hline $\begin{array}{l}\text { National trading } \\
\text { scheme }\end{array}$ & 4 & 1 & 0 & 1 & 30 & 4 & 2 & 2 & 44 \\
\hline CDM & 2 & 0 & 18 & 2 & 2 & 6 & 0 & 1 & 31 \\
\hline $\mathrm{JCM}$ & 10 & 1 & 2 & 0 & 0 & 3 & 0 & 1 & 17 \\
\hline
\end{tabular}

CDM = Clean Development Mechanism, JCM = Joint Crediting Mechanism, NDC = nationally determined contribution.

a Parties counted in this row are those that expressly claim in their NDCs the intention either to use market mechanisms or to consider their use.

b Parties counted here are not only those that claim to have the intention to use or to consider the use of market mechanisms, but also those Parties that actually use market mechanisms (to the extent of the authors' knowledge) but do not mention such use in their NDCs. Therefore, the number of countries using all types of market mechanisms is higher than the number of countries declaring their intention to use market mechanisms in their NDC.

c Additionally, since many countries use more than one type of market mechanism, the total for countries using market mechanisms exceeds the actual total number of countries

Source: Institute for Global Environmental Strategies (IGES). 2019b. Nationally Determined Contributions Database, version 7.1 (July 2019). https://pub.iges.or.jp/pub/iges-ndc-database (accessed 15 December 2019).

\section{" 102 countries, representing $58.6 \%$ of the global GHG emissions, stated in their NDCs that they are considering or intending to use market mechanisms."}

5 Emissions data were calculated based on the 2018 publication " $\mathrm{CO}_{2}$ Emissions from Fuel Combustion 2018" by the International Energy Agency (IEA). 


\subsection{Regional Context}

ADB has 68 member countries, 49 of which are from Asia and the Pacific. Of these 49 member countries, 41 are developing member countries (DMCs) receiving assistance from ADB. By analyzing NDCs communicated by these countries, exact statements from their NDCs were used to categorize the 41 DMCs into three groups as shown in Table 2:

- Group 1 comprises 20 DMCs that expressed their intent or consideration of using market mechanisms in their NDCs.

- Group 2 consists of 16 DMCs that did not state specifically or were not clear in their NDCs whether they would be using or considering market mechanisms.

- Group 3 is made up of five DMCs that expressed that they had no intention to use market mechanisms in their NDCs.

\section{Table 2: Intention to Use Market Mechanisms Based on Statements in the Nationally Determined Contributions}

\begin{tabular}{|c|c|c|}
\hline Group 1 & Group 2 & Group 3 \\
\hline YES OR MAY CONSIDER & NOT CLEAR & NO \\
\hline $\begin{array}{l}\text { Afghanistan } \\
\text { Armenia } \\
\text { Bangladesh } \\
\text { Bhutan } \\
\text { Cambodia } \\
\text { China, People's Republic of } \\
\text { Fiji } \\
\text { India } \\
\text { Indonesia } \\
\text { Kazakhstan } \\
\text { Kiribati } \\
\text { Lao People's Democratic Republic } \\
\text { Mongolia } \\
\text { Myanmar } \\
\text { Nepal } \\
\text { Pakistan } \\
\text { Samoa } \\
\text { Solomon Islands } \\
\text { Thailand } \\
\text { Viet Nam }\end{array}$ & $\begin{array}{l}\text { Azerbaijan } \\
\text { Cook Islands } \\
\text { Georgia } \\
\text { Kyrgyz Republic } \\
\text { Maldives } \\
\text { Nauru } \\
\text { Niue } \\
\text { Papua New Guinea } \\
\text { Philippines } \\
\text { Sri Lanka } \\
\text { Tajikistan } \\
\text { Timor-Leste } \\
\text { Tonga } \\
\text { Turkmenistan } \\
\text { Uzbekistan } \\
\text { Vanuatu }\end{array}$ & $\begin{array}{l}\text { Malaysia } \\
\text { Marshall Islands } \\
\text { Micronesia, Federated States of } \\
\text { Palau } \\
\text { Tuvalu }\end{array}$ \\
\hline TOTAL: 20 countries & TOTAL: 16 countries & TOTAL: 5 countries \\
\hline
\end{tabular}

Note: Group 1 comprises 20 DMCs of ADB that expressed their intent or consideration of using market mechanisms in their NDCs. Group 2 consists of 16 DMCs that did not state specifically or were not clear in their NDCs whether they would be using or considering market mechanisms. Group 3 is made up of five DMCs that expressed that they had no intention to use market mechanisms in their NDCs. Source: Asian Development Bank (Sustainable Development and Climate Change Department). 
The 41 DMCs of ADB in Asia and the Pacific accounted for $43.1 \%$ of the total global GHG emissions (equivalent to $15.2 \mathrm{GtCO}_{2} \mathrm{e}$ ) in 2018 as shown in Figure 3. Out of the $41 \mathrm{DMCs}$, the 20 countries in Group 1 represented $95.6 \%$ of the emissions in developing Asia and the Pacific (or $41.2 \%$ out of $43.1 \%$ of global emissions), indicating that most emissions from the region come from countries that consider or intend to use market mechanisms to accomplish NDC targets. The remaining $21 \mathrm{DMCs}$, which account for $4.4 \%$ of the emissions from all DMCs either have no clear intention to use market mechanisms (2.6\% of DMCs' emissions) or have specifically stated that they will not use market mechanisms (1.8\% of DMCs' emissions).

Other Parties in the region that are not among ADB's 41 DMCs account for $6.7 \%$ of total global emissions. It includes developed members like Australia and Japan, or graduated DMCs like Brunei Darussalam and Singapore. In total, the Asia and Pacific region ${ }^{6}$ contributed almost half of the total global GHG emissions (49.8\%) in 2018.

\section{Figure 3: Share of ADB's Developing Members in Global and Regional Greenhouse Gas Emissions, 2018}

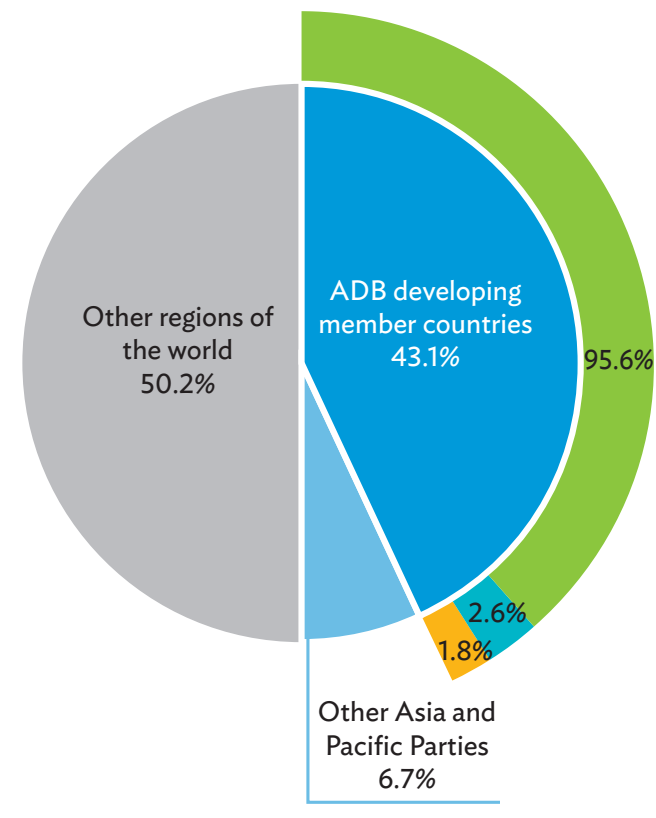

41.2\% Group 1: 20 countries

1.1\% Group 2: 16 countries

$\mathbf{0 . 8 \%} \quad$ Group 3: 5 countries

$\mathrm{ADB}=$ Asian Development Bank

Note: Group 1 comprises 20 developing member countries of ADB that expressed their intent or consideration of using market mechanisms in their NDCs. Group 2 consists of 16 countries that did not state specifically or were not clear in their NDCs whether they would be using or considering market mechanisms. Group 3 is made up of five countries that expressed that they had no intention to use market mechanisms in their NDCs.

Data source: Global Carbon Atlas. 2019. $\mathrm{CO}_{2}$ Emissions. http://www.globalcarbonatlas.org/en/ $\mathrm{CO}_{2}$-emissions. (accessed 9 December 2019).

It is important to note that even though the intention of Group 2 countries to use market mechanisms is not clear from their NDCs, these countries could still be participating in and conducting activities related to market-based cooperation as considered appropriate.

6 Asia and the Pacific includes the Democratic People's Republic of Korea and 49 regional members of ADB consisting of 41 DMCs currently receiving ADB assistance, five developing members that have graduated from regular ADB assistance on the basis of set criteria (Brunei Darussalam; Hong Kong, China; the Republic of Korea; Singapore; and Taipei,China), and three developed members (Australia, Japan, and New Zealand) (ADB 2019b). 
The Philippines, for example, did not mention the use of market mechanisms in its NDC, but is exploring the potential of carbon pricing instruments to achieve its NDC targets (PMR 2019f; Senate of the Philippines 2018). It joined the Partnership for Market Readiness (PMR) in 2017 and is reviewing potential market-based instruments (MBIs) for the implementation of the climate mitigation goals, and for assistance in determining the most effective and feasible carbon pricing instruments to support the implementation of the NDC within the energy sector (PMR 2019f). The Philippines is also preparing a virtual pilot for Article 6, funded by the Swedish Energy Agency (SEA) (NICA 2019). It is worth noting as well that the country has experience in implementing CDM and JCM projects (UNEP DTU Partnership n.d.; IGES 2019a) even though these were not mentioned in its NDC.

On a different note, Uzbekistan did mention CDM in its NDC among the mitigation measures that the country already implements. However, the NDC does not provide any information about its intention or consideration of using different forms of market mechanisms to achieve its NDC targets.

Countries in both Groups 2 and 3 could have ongoing and planned initiatives related to market mechanisms. However, for the purpose of this paper, NDC statements were used as the main source for defining the countries' intentions to use market mechanisms and therefore focuses on countries in Group 1, which have specifically expressed interest in or consideration of using different forms of market mechanisms in their NDCs.

\section{"20 out of 49 ADB members in Asia and the Pacific, representing 41.2\% of global GHG emissions, are considering or intending to use market mechanisms in accomplishing NDCs."}

\section{Statements of Market Mechanisms in Nationally Determined Contributions}

Countries have varying statements on how they intend to use market mechanisms in their respective NDCs. Exact extracts from NDCs of Group 1 DMCs that reflect the intent or consideration to use market mechanisms are shown in Table 3. The stated intentions range from unspecified statements such as "does not exclude the use of carbon markets" (Bangladesh) and general expectations of international support, to specific references to higher incomes as a result of mitigation activities (Nepal) and carbon finance contributing to the setting up of national climate change funds (Kiribati and Solomon Islands).

Countries with relatively clear interest in using market mechanisms include Indonesia, Kazakhstan, Mongolia, Pakistan, and the People's Republic of China (PRC). Indonesia and Pakistan both mentioned Article 6 of the Paris Agreement in their NDCs along with considerations of using market mechanisms. Indonesia specified that it "welcomes bilateral, regional, and international cooperation in NDC implementation, as recognized under Article 6 of the Paris Agreement" (Government of Indonesia 2016). Pakistan mentioned that it is considering the integration of market mechanisms in the context of Article 6 of the Paris Agreement. The PRC has explicitly defined its goals of implementing a national emissions trading system (ETS), although it has not made reference to linking the domestic ETS to international markets in its NDC. Most of the other countries among the 20 DMCs in Group 1 expressed interest or consideration of using international market mechanisms in their respective NDCs.

Countries that have specified they will consider use of market mechanisms include Kiribati, the Lao People's Democratic Republic (Lao PDR), and Solomon Islands. Kiribati and Solomon Islands "will consider market-based mechanisms," (Government of Kiribati 2016; and Government of Solomon Islands 2016), while the Lao PDR "will consider carbon credits" (Government of the Lao People's Democratic Republic 2015). Armenia specified the possibility of using carbon markets "in case of 
non-exceeding its total emissions quota" (Government of Armenia 2015). Other countries have relatively generic statements about the use of market mechanisms in their NDCs.

Generally, market mechanisms or MBls are discussed with regard to the energy and industry sectors, where subsidies, feed-in tariffs, and tax exemptions are also mentioned as means of enhancing renewable energy deployment and energy efficiency (Amponin and Evans 2016). For instance, Bhutan will pursue development of clean, renewable energy, specifically hydropower electricity, in the country and within the region through market mechanisms. India's experience in implementing national market mechanisms to promote renewable energy development and energy saving in the country could be relevant as it intends to test "a careful mix of market mechanisms together with fiscal instruments and regulatory interventions" (Government of India 2016).

\section{Table 3: Statements on the Use of Market Mechanisms in Nationally Determined Contributions}

\begin{tabular}{|c|c|}
\hline DMC & References to Market Mechanisms in Respective NDCs ${ }^{a}$ \\
\hline Afghanistan & $\begin{array}{l}\text { "Climate mitigation gaps and barriers and support needs [in the] energy efficiency in buildings } \\
\text { and in transport sector [included] carbon finance and project development skills." }\end{array}$ \\
\hline Armenia & $\begin{array}{l}\text { "In case of non-exceeding its total emissions quota ( } 633 \text { million tons) set for the period of } \\
2015-2050 \text { Armenia can credit non-utilized reduction to 'carbon market,' or transfer it to } \\
\text { the balance of emissions limitation envisaged for the period of 2050-2100." } \\
\text { "Develop an appropriate legislative and institutional framework for adequate financial } \\
\text { assistance. For this purpose, a targeted financial mechanism consisting of two components } \\
\text { should be created to finance climate change mitigation and adaptation projects: } \\
\text { (i) The first - internal (domestic) climate revolving civil fund, to be replenished on a } \\
\text { permanent basis with allocations from environmental fees and ecosystem service fees, } \\
\text { including 'carbon taxing.' } \\
\text { (ii) The second - external (international) financial mechanisms with resource provision } \\
\text { following the principle of additionality, such as the Green Climate Fund, the Adaptation } \\
\text { Fund, the Global Environmental Facility, bilateral and multilateral funds, and other } \\
\text { sources." }\end{array}$ \\
\hline Bangladesh & $\begin{array}{l}\text { "Net contribution of international market-based mechanism: } \\
\text { Bangladesh does not rule out the use of international market-based mechanisms in line } \\
\text { with agreed modalities and accounting rules." }\end{array}$ \\
\hline Bhutan & $\begin{array}{l}\text { "Presently, Bhutan offsets } 4.4 \text { million tons of } \mathrm{CO}_{2} \text { e through exports of hydroelectricity. In } \\
\text { addition, Bhutan can offset up to } 22.4 \text { million tons of } \mathrm{CO}_{2} \text { e per year by } 2025 \text { in the region } \\
\text { through the export of electricity from our clean hydropower projects." } \\
\text { "5. Promote clean renewable energy generation: Pursue sustainable and clean hydropower } \\
\text { development with support from Clean Development Mechanism (CDM) or other climate } \\
\text { market mechanisms to reduce emissions within Bhutan and the region by exporting surplus } \\
\text { electricity." } \\
\text { "Mitigation measures to manage and reduce emissions in priority areas and sectors will need } \\
\text { to be implemented through relevant low emission development strategies, programs and } \\
\text { plans. A combination of fiscal incentives within the } 2007 \text { National Environment Protection } \\
\text { Act (NEPA) and } 2010 \text { Economic Development Policy, financial and technical support } \\
\text { from international climate mechanisms, and enforcement of existing legislation for } \\
\text { environmental safeguards such as NEPA and Environment Assessment Act } 2000 \text { will also be } \\
\text { required." }\end{array}$ \\
\hline Cambodia & $\begin{array}{l}\text { "The support received will be channeled through bilateral and multilateral mechanisms, } \\
\text { including market-based mechanisms." }\end{array}$ \\
\hline
\end{tabular}


Table 3 continued

\begin{tabular}{|c|c|}
\hline DMC & References to Market Mechanisms in Respective NDCs \\
\hline $\begin{array}{l}\text { China, } \\
\text { People's } \\
\text { Republic of }\end{array}$ & $\begin{array}{l}\text { "Promoting Carbon Emission Trading Market: } \\
\text { - To build on carbon emission trading pilots, steadily implementing a nationwide carbon } \\
\text { emission trading system and gradually establishing the carbon emission trading } \\
\text { mechanism so as to make the market play the decisive role in resource allocation; and } \\
\text { - To develop mechanisms for the reporting, verifying and certificating of carbon emissions } \\
\text { and to improve rules and regulations for carbon emission trading to ensure openness, } \\
\text { fairness and justice in the operation of the carbon emission trading market." }\end{array}$ \\
\hline Fiji & $\begin{array}{l}\text { "In order to achieve rapid and cost-efficient mitigation, a combination of robust global } \\
\text { market-based mechanisms and direct aid transfers will be essential. Achieving our } \\
\text { conditional goal will require substantial funding including fully functional bilateral, regional } \\
\text { and international market mechanisms such as the CDM." }\end{array}$ \\
\hline India & $\begin{array}{l}\text { "At the same time India is not relying solely on budgetary resources and is experimenting } \\
\text { with a careful mix of market mechanisms together with fiscal instruments and regulatory } \\
\text { interventions to mobilize finance for climate change." }\end{array}$ \\
\hline Indonesia & $\begin{array}{l}\text { "Indonesia welcome[s] bilateral, regional and international cooperation in the NDC } \\
\text { implementation as recognized under Article } 6 \text { of the Paris Agreement, that facilitate } \\
\text { and expedite technology development and transfer, payment for performance, technical } \\
\text { cooperation, and access to financial resources to support Indonesia's climate mitigation and } \\
\text { adaptation efforts towards a climate resilient future." }\end{array}$ \\
\hline Kazakhstan & $\begin{array}{l}\text { "Kazakhstan supports inclusion of market-based mechanisms in the } 2015 \text { agreement, and } \\
\text { the opportunity to use carbon units recognized by the UNFCCC. Kazakhstan retains the } \\
\text { option of using market-based mechanisms under the UNFCCC. Kazakhstan will consider } \\
\text { adequately discounting international units for compliance to ensure a contribution to net } \\
\text { global emission reductions." }\end{array}$ \\
\hline Kiribati & $\begin{array}{l}\text { "Kiribati will consider market-based mechanisms to support establishment and operation } \\
\text { of a National Climate Change Trust Fund." }\end{array}$ \\
\hline Lao PDR & $\begin{array}{l}\text { "The Central Bank of Lao PDR will consider carbon credits and low interest loans as sources } \\
\text { of financing for renewable energy and agricultural projects carried out by small and medium } \\
\text { enterprises." } \\
\text { "Implementation of the electricity export agreement along with development of a Nationally } \\
\text { Appropriate Mitigation Action (NAMA), and preparedness for future carbon market } \\
\text { mechanism." }\end{array}$ \\
\hline Mongolia & $\begin{array}{l}\text { "Those [INDC mitigation policies and measures] and other potentially more ambitious } \\
\text { commitments are contingent on gaining access to new technologies and sources of finance } \\
\text { through internationally agreed mechanisms and instruments under the auspices of the } \\
\text { UNFCCC." } \\
\text { "Mongolia is interested in opportunities to access international climate funds namely the } \\
\text { Green Climate Fund and in participation with crediting mechanisms to implement these } \\
\text { measures." }\end{array}$ \\
\hline Myanmar & $\begin{array}{l}\text { Myanmar also intends to build its capacity to effectively and efficiently [to] participate in } \\
\text { future market-based mechanisms. }\end{array}$ \\
\hline
\end{tabular}


Table 3 continued

\begin{tabular}{|c|c|}
\hline DMC & References to Market Mechanisms in Respective NDCs ${ }^{a}$ \\
\hline Nepal & $\begin{array}{l}\text { "Nepal requires bilateral and multilateral grant support in the following priority areas to meet } \\
\text { both qualitative and quantitative targets: } \\
\text { f) Provide better price from carbon markets to ensure an equitable benefit sharing } \\
\text { mechanisms and maximize benefits at the local level to help sustainable management of } \\
\text { forests. } \\
\text { g) Sell carbon credits at a better price from its renewable energy and REDD+ programs." }\end{array}$ \\
\hline Pakistan & $\begin{array}{l}\text { "Other key areas relate to (a) establishment of organizational structure at the national and } \\
\text { subnational levels; (b) use of CDM and other market mechanisms to support climate } \\
\text { change activities; (c) capacity building; and ( } d \text { ) financing of climate change regime using } \\
\text { national and international resources. The Ministry is actively reviewing policy considerations } \\
\text { for further integration of market mechanisms in responding to emerging threats in the context } \\
\text { of Article } 6 \text { of the Paris Agreement." }\end{array}$ \\
\hline Samoa & $\begin{array}{l}\text { "Samoa currently uses no market mechanisms but is willing to pursue the potential of } \\
\text { markets where possible." }\end{array}$ \\
\hline $\begin{array}{l}\text { Solomon } \\
\text { Islands }\end{array}$ & $\begin{array}{l}\text { "Solomon Islands will consider other avenues as well as market-based mechanisms to } \\
\text { support establishment and operation of a National Climate Change Trust Fund." }\end{array}$ \\
\hline Thailand & $\begin{array}{l}\text { "Thailand recognizes the important role of market-based mechanisms to enhance the cost } \\
\text { effectiveness of mitigation actions, and therefore will continue to explore the potentials of } \\
\text { bilateral, regional and international market mechanisms as well as various approaches } \\
\text { that can facilitate, expedite and enhance technology development and transfer, capacity } \\
\text { building and access to financial resources that support Thailand's efforts towards achieving } \\
\text { sustainable, low-carbon and climate-resilient growth, as appropriate." }\end{array}$ \\
\hline Viet Nam & $\begin{array}{l}\text { "In 2012, the National Green Growth Strategy was approved, which includes mitigation } \\
\text { targets and measures; and regulations on linking with international carbon markets." } \\
\text { "Policy framework to support the implementation of the goal to mitigate } \\
\text { GHG Emissions: Decision 1775/QĐ-TTg on "Management of GHG emissions; management } \\
\text { of carbon credit trading activities to the world market" (11/2012)." } \\
\text { "Apply market instruments to promote structural change and improve energy efficiency; } \\
\text { encourage the use of clean fuels; support the development of renewable energy; implement } \\
\text { the roadmap to phase out subsidies for fossil fuels." }\end{array}$ \\
\hline
\end{tabular}

$\mathrm{ADB}=$ Asian Development Bank, $\mathrm{CDM}=$ Clean Development Mechanism, $\mathrm{CO}_{2} \mathrm{e}=$ carbon dioxide equivalent, $\mathrm{DMC}=$ developing member country, GCF = Green Climate Fund, GDP = gross domestic product, GHG = greenhouse gas, INDC = intended nationally determined contribution, Lao PDR = Lao People's Democratic Republic, NAMA = Nationally Appropriate Mitigation Action, $\mathrm{NDC}=$ nationally determined contribution, REDD + = reducing emissions from deforestation and forest degradation, plus the sustainable management of forests, and the conservation and enhancement of forest carbon stocks in developing countries, UNFCCC = United Nations Framework Convention on Climate Change.

Note: All statements were quoted from respective NDCs of each country. The full list of NDC sources can be found from reference list. Source: United Nations Framework Convention on Climate Change (UNFCCC) n.d.d. Nationally Determined Contribution (NDC) Registry. https://www4.unfccc.int/sites/NDCStaging/Pages/All.aspx (accessed 15 December 2019). 


\section{LINKING NATIONALLY DETERMINED CONTRIBUTION TARGETS WITH MARKET MECHANISMS}

As mentioned previously, of the 41 DMCs ADB has in Asia and the Pacific, 20 DMCs have expressed interest in using market mechanisms in pursuing their nationally determined contributions (NDCs) referred as Group 1 DMCs. Though the information presented in the NDCs is not sufficient to link the conditionality of NDC targets with market mechanisms for all countries, this section presents an analysis of how market mechanisms are linked with the conditionality and type of NDC targets for Group 1 DMCs. This analysis provides an overview of how the use of market mechanisms is presented in different types of NDCs of these 20 countries included under Group 1.

Figure 4 provides an overview of the conditionality of economy-wide targets specified in the NDCs of Group 1 DMCs.

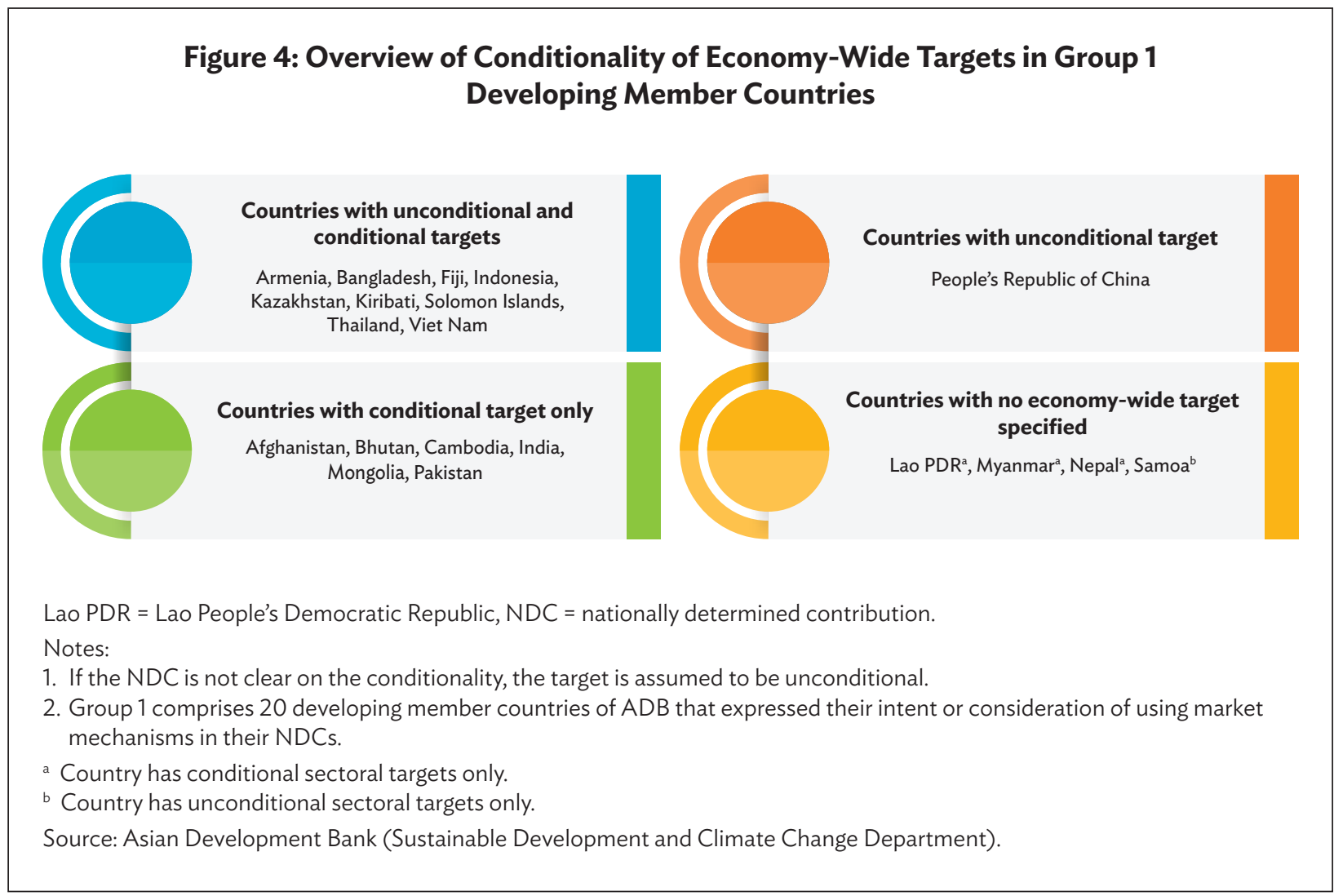

\subsection{Countries with Unconditional and Conditional Targets in Nationally Determined Contributions}

It is observed that many countries expect international support to assist them in achieving their conditional NDC targets. Table 4 shows the countries among Group 1 DMCs with economy-wide conditional targets. Appendix 1 presents a more detailed overview of the conditional and unconditional targets. 
The division of NDC targets into those to be achieved using domestic resources (unconditional) and more ambitious targets to be achieved with international support (conditional) is common among lowerand middle-income countries. The most obvious use of market mechanisms for achieving the NDC is when market mechanisms are used towards the conditional part of the NDC, since it would address mitigation actions in addition to what the country has committed to do on their own. However, there are many types of international support and to understand the possible role of international markets, it is useful to use the distinction between approaches that concern direct investments or financial support for mitigation activities, and approaches that involve support for mitigation policies (Strand 2017).

Table 4: Conditional Reduction Targets of Group 1 Countries

\begin{tabular}{|l|c|c|c|c|c|}
\hline Country & Base Year & Target Year & Target Type & $\begin{array}{c}\text { Unconditional } \\
\text { Target }\end{array}$ & $\begin{array}{c}\text { Conditional } \\
\text { Target }^{\text {a }}\end{array}$ \\
\hline Afghanistan & 2005 & 2030 & $\%$ of BAU & - & $13.6 \%$ \\
\hline Armenia & - & 2050 & $\begin{array}{c}\text { Absolute } \\
\text { emissions per } \\
\text { capita }\end{array}$ & $\begin{array}{c}\text { 5.4 tons per } \\
\text { capita yearly }\end{array}$ & $\begin{array}{c}2.07 \text { tons per } \\
\text { capita yearly }\end{array}$ \\
\hline Bangladesh & - & 2030 & $\%$ of BAU & $5 \%$ & $15 \%$ \\
\hline Cambodia & - & 2030 & $\%$ of BAU & - & $\begin{array}{c}27 \% \text { in energy } \\
\text { and industries }\end{array}$ \\
\hline Fiji & - & 2030 & $\%$ of BAU & $10 \%$ & $30 \%(+20 \%)$ \\
\hline India & 2005 & 2030 & $\%$ relative to GDP & - & $33 \%-35 \%$ \\
\hline Indonesia & 2005 & 2030 & $\%$ of BAU & $29 \%$ & $41 \%$ \\
\hline Kazakhstan & 1990 & 2030 & $\%$ of base year & $15 \%$ & $25 \%$ \\
\hline Kiribati & - & 2030 & $\%$ of BAU & $12.8 \%$ & $61.8 \%(+49 \%)$ \\
\hline Mongolia & - & 2030 & $\%$ of BAU & - & $14 \%$ \\
\hline Pakistan & - & 2030 & $\%$ of BAU & - & $20 \%$ \\
\hline Solomon Islands & 2015 & 2030 & $\%$ of base year & $30 \%$ & $75 \%(+45 \%)$ \\
\hline Thailand & 2005 & 2030 & $\%$ of BAU & $20 \%$ & $25 \%$ \\
\hline \multirow{2}{*}{ Viet Nam } & 2010 & 2030 & $\%$ of BAU & $8 \%$ & $25 \%$ \\
\hline & 2010 & 2030 & $\begin{array}{c}\text { emissions intensity } \\
\text { per unit GDP }\end{array}$ & $20 \%$ & $30 \%$ \\
\hline
\end{tabular}

$(-)=$ Information not available, BAU = business-as-usual, GDP = gross domestic product.

Note: Group 1 comprises 20 developing member countries of ADB that expressed their intent or consideration of using market mechanisms in their NDCs.

a Some NDCs specify that the conditional targets are additional to the unconditional targets while some state the conditional targets only in broad terms (i.e., as a total conditional reduction target). Targets that were expressed in the NDCs as additional to unconditional targets are reflected in the column with a plus symbol $(+)$.

Source: United Nations Framework Convention on Climate Change (UNFCCC) n.d.d. Nationally Determined Contribution (NDC) Registry. https://www4.unfccc.int/sites/NDCStaging/Pages/All.aspx (accessed 15 December 2019).

In most cases, it is not clear whether the international support is expected to create mitigation activities directly such as through projects or programs under baseline-crediting mechanisms, or if it should be used to develop policies and measures that achieve mitigation e.g., under a bilateral cooperative approach. Thus, the link between the use of carbon markets and the conditional target is not very well specified or elaborated. The following discussions show an overview of countries with conditional and unconditional NDC targets and how their targets relate to their intention to use market mechanisms. 
Bangladesh is one example of a country with both a conditional and an unconditional target: the unconditional target of "[reducing] GHG emissions by 5\% (12 million metric tons of carbon dioxide equivalent $\left[\mathrm{MtCO}_{2} \mathrm{e}\right]$ ) from business-as-usual (BAU) levels by 2030 in the power, transport and industry sectors, and a conditional target of $15 \%\left(36 \mathrm{MtCO}_{2} \mathrm{e}\right.$ ) subject to appropriate international support in the form of finance, investment, technology development and transfer, and capacity building" (Government of Bangladesh 2015). The country's NDC states that "Bangladesh does not rule out the use of international market-based mechanisms in line with agreed modalities and accounting rules" (Government of Bangladesh 2015), but there is no further elaboration regarding the sectors where such use is intended and whether this would be a possibility for achieving the conditional target.

Indonesia has a similar approach to Bangladesh and "welcomes bilateral, regional and international market mechanisms that facilitate and expedite technology development and transfer, payment for performance, technical cooperation, and access to financial resources to support Indonesia's climate mitigation and adaptation efforts towards a climate resilient future" (Government of Indonesia 2016). Thus, it is also an example of a country with a conditional target and an ambition to use international carbon markets, but presents no explicit link between these two elements.

Armenia has set a long-term target of achieving ecosystem-neutral GHG emissions by 2050, provided that it receives adequate international financial, technological, and capacity-building assistance. International carbon markets are not mentioned in relation to achieving the conditional target but are referred to as an option if Armenia overachieves its target.

Kazakhstan provides a possible link between international carbon markets and the conditional target when stating that the reduction ambition will increase from 15\% to 25\% in "GHG emissions by 31 December 2030 compared to the base year, subject to additional international investments, access to low carbon technologies transfer mechanism, green climate funds and flexible mechanism for country with economy in transition" (Government of Kazakhstan 2016). "Flexible mechanism" is a Kyoto Protocol term for a carbon market mechanism, and the possibility of using such mechanisms is also mentioned in the NDC: "Kazakhstan retains the option of using market-based mechanisms under the UNFCCC" (Government of Kazakhstan 2016).

Thailand highlights the role of market-based mechanisms in enhancing the cost-effectiveness of mitigation actions, increasing the ambition from $20 \%$ to $25 \%$ conditional on international support. It states in its NDC that it "will continue to explore the potentials of bilateral, regional and international market mechanisms" (Government of Thailand 2015). Again, there is no specific link to the conditional target, but there is a reference to international carbon markets as a means of achieving the costeffectiveness of mitigation actions.

Viet Nam's NDC makes a coupling between the conditional target and international support, where it is stated that the $8 \%$ contribution could be increased to $25 \%$ if international support is received through bilateral and multilateral cooperation, as well as through the implementation of new mechanisms under the Global Climate Agreement.

Fiji also makes such a concrete link: "Achieving our conditional goal will require substantial funding including fully functional bilateral, regional and international market mechanisms such as the CDM" (Government of Fiji 2016).

In some cases, market-based mechanisms are intended for the capitalization of national climate change trust funds. Kiribati will consider market-based mechanisms to support the establishment and operation of a National Climate Change Trust Fund, while Solomon Islands will consider "other avenues as well as market-based mechanisms" to do the same (Government of Kiribati 2016; and Government 
of Solomon Islands 2016). In these cases, selling of mitigation outcomes will be used as a source of income to national funds.

\subsection{Countries with Conditional Targets in Nationally Determined Contributions}

In countries that have specified a conditional target but no unconditional target, such as Afghanistan, Bhutan, Cambodia, India, Mongolia, and Pakistan, the link between the NDC target and use of market mechanisms is typically direct.

Cambodia states in its NDC that, "The support received will be channeled through bilateral and multilateral mechanisms, including market-based mechanisms" (Government of Cambodia 2017). Another country with a conditional target is Mongolia, which mentions that its "[mitigation contributions] and other potentially more ambitious commitments are contingent upon gaining access to new technologies and sources of finance through internationally agreed mechanisms and instruments under the auspices of the UNFCCC" (Government of Mongolia 2016). Though the term "mechanisms and instruments" was broadly used in this statement, Mongolia further states that it is "interested in opportunities to access international climate funds namely the Green Climate Fund and in participation with crediting mechanisms to implement these measures" (Government of Mongolia 2016), which could be seen as interest in using market mechanisms under the Paris Agreement.

In other countries, this link is not as explicit. Pakistan mentions that its "indicated mitigation potential can only be realized through international support in the form of financial grants, technical assistance, technology development and transfer and capacity building" (Government of Pakistan 2016). Furthermore, it has announced its interest in using international mechanisms: "The Ministry is actively reviewing policy considerations for further integration of market mechanisms in responding to emerging threats in the context of Article 6 of the Paris Agreement" (Government of Pakistan 2016). In a similar way, Afghanistan's NDC does not clearly express that it will use market mechanisms to achieve its conditional NDC target. Its NDC only states that it needs capacity building support in "carbon finance" as part of its "Climate Mitigation Gaps and Barriers and Support Needs" for the energy efficiency sector (buildings and transport).

In a few cases, countries with a conditional target are very specific about the type and source of support they expect. One example is India, which states as part of its conditional target that it aims "to achieve about $40 \%$ cumulative electric power installed capacity from nonfossil fuel based energy resources by 2030 with the help of transfer of technology and low cost international finance including from Green Climate Fund (GCF)" (Government of India 2016). Thus, there is an expectation of direct support for specific activities in a specific sector, and one source of funding is mentioned. The role of carbon markets in this case is not mentioned. Generally, India's clear position on the need to transition CDM projects into the Paris Agreement for the post-2020 period indicates at least a willingness to continue ongoing projects but it cannot be read from the NDC that there is an intention to use international carbon markets for the conditional target.

In the case of Bhutan, its NDC mentions that it "call[s] on the international community to support [its] efforts to mitigate and adapt to climate change" (Government of Bhutan 2015). Though Bhutan has an economy-wide mitigation target, its NDC only mentions the use of market mechanisms specific to promoting clean hydropower development by exporting surplus electricity. It specifies in the NDC that the successful implementation of its intended mitigation actions will depend on the level of financial and technical support received, and that "international support will be essential to ensure success in implementing the strategies, plans and actions for low GHG development" (Government of Bhutan 2015). 


\subsection{Countries with Unconditional Targets in Nationally Determined Contributions}

The People's Republic of China (PRC) has not specified the conditionality of its targets in its NDC unlike the other DMCs of ADB. For this reason, the PRC's NDC target is interpreted as unconditional in this study. The PRC also does not state the need for international support in achieving its NDCs. Instead, it expresses its readiness to provide support to other countries and its willingness to "take on international commitments that match its national circumstances, current development stage and actual capabilities by enhancing mitigation and adaptation actions and further strengthening South-South Cooperation on climate change" (Government of the People's Republic of China 2015). The PRC's intention to use market mechanisms focuses on domestic emissions trading (IGES 2019b and ICAP 2019b) and it is unclear if south-south cooperation on mitigation will include international carbon markets.

\subsection{Countries with Sector Policy Targets in Nationally Determined Contributions}

Not all countries have economy-wide mitigation targets but instead include specific sector targets in their NDCs (Appendix Table A1). Nepal has set a sector target and mentions the contribution of carbon finance in its two priority sectors (energy and land use, land-use change and forestry [LULUCF]). Nepal expects the post-2020 market to "provide better price from carbon markets to ensure an equitable benefiting mechanism and maximize benefits at the local level to help sustainable management of forests" and "sell carbon credits at a better price from its renewable energy and REDD+ programmes" (Government of Nepal 2016). This shows an expectation that carbon finance can support mitigation activities in specific sectors.

Samoa states that it "is willing to pursue the potential of markets where possible" (Government of Samoa 2016). In its NDC, Samoa commits to generating $100 \%$ of its electricity from renewable energy sources by 2025 , which is conditional on reaching the 100\% renewable electricity target by 2017 and receiving external assistance to maintain the contribution of renewable sources at $100 \%$ through to 2025 . This case shows an expectation that the use of international carbon markets can support economic growth using only renewable energy.

In the NDC of Lao People's Democratic Republic (Lao PDR), the government states that "the Central Bank of Lao PDR will consider carbon credits and low interest loans as sources of financing for renewable energy and agricultural projects carried out by small and medium enterprises" (Government of the Lao People's Democratic Republic 2015). But there is as yet no clarification of how this relates to the NDC target.

Myanmar does not specify an economy-wide mitigation target in its first NDC but mentions that it will "present projections of anticipated GHG impact assessments in future revisions of its INDC" (Government of Myanmar 2016). Myanmar, however, enumerates a list of mitigation actions it will undertake which are "conditional on [the] availability of international support, as its contribution to global action to reduce future emissions of greenhouse gases" (Government of Myanmar 2016). In Myanmar's NDC, sectoral mitigation actions were specified but targets were only quantified for energy and LULUCF sectors using non-GHG targets (e.g., percentage forest cover, savings from electricity consumption, etc.). The country was especially specific with its energy sector targets and provided targets for energy efficiency, renewable energy, cookstove distribution, and others, which might signal that its intent to "build its capacity to effectively and efficiently participate in future market-based mechanisms" (Government of Myanmar 2016), could be directed toward market mechanisms for the energy sector. 


\section{COUNTRY EXPERIENCE WITH MARKET MECHANISMS}

This section provides an overview of the experience of Group 1 developing member countries (DMCs) of the Asian Development Bank (ADB) with pre-Paris Agreement market mechanisms and their engagement in ongoing preparatory activities for the new generation of carbon markets. This analysis helps to further understand ADB DMCs' preparedness for accessing new carbon markets under Article 6 of the Paris Agreement.

This section presents an analysis of DMC experience related to project-based market mechanisms such as the Clean Development Mechanism (CDM) and the Joint Crediting Mechanism (JCM) (Section 4.1), Nationally Appropriate Mitigation Actions (NAMAs) (Section 4.2), and emission trading systems (ETSs) (Section 4.3). On the basis of past experience with carbon markets, Section 4.3 presents an overview of ongoing activities that can potentially determine countries' preparedness for new market mechanisms.

\subsection{Experience with Project-Based Mechanisms}

ADB's DMCs show a considerable breadth of experience related to project-based mechanisms including CDM and JCM. Around $80 \%$ of all CDM projects and $90 \%$ of all JCM projects are hosted by Asia and the Pacific (UNEP DTU Partnership n.d.; IGES 2019a). As of February 2020, Group 1 countries represent $77.8 \%$ of all registered CDM projects in the world, and $80 \%$ of all registered JCM projects out of 17 partner countries under JCM (UNFCCC 2020; JCM n.d.). Breakdown of CDM and JCM projects are shown in Table 5. Exact numbers of CDM and JCM projects among the Group 1 countries is presented in Appendix 3.

Table 5: Experience with Project-Based Mechanisms among Group 1 Countries

\begin{tabular}{|l|l|l|}
\hline $\begin{array}{l}\text { Experience with Project- } \\
\text { Based Mechanisms }\end{array}$ & \multicolumn{1}{|c|}{ CDM and JCM } & \multicolumn{1}{c|}{ CDM only } \\
\hline None & Afghanistan, Kazakhstan ${ }^{\text {, }}$ Kiribati, Samoa, Solomon Islands \\
\hline Limited (<10 projects) & Bangladesh, Mongolia, Myanmar & Armenia, Bhutan, Fiji, Nepal \\
\hline Moderate ( $>10$ projects $)$ & Cambodia, Lao PDR & Pakistan \\
\hline Advanced ( $>100$ projects $)$ & Indonesia, Thailand, Viet Nam & India, PRC \\
\hline
\end{tabular}

CDM = Clean Development Mechanism, JCM = Joint Crediting Mechanism, Lao PDR = Lao People's Democratic Republic, PRC = People's Republic of China, UNFCCC = United Nations Framework Convention on Climate Change.

Note: Group 1 comprises 20 developing member countries of ADB that expressed their intent or consideration of using market mechanisms in their NDCs.

a In accordance with the COP conclusion (FCCC/CP/2001/13/Add.4, section V.C.) and following the ratification by Kazakhstan of the Kyoto Protocol on 19 June 2009 and its entry into force on 17 September 2009, Kazakhstan is considered an Annex I Party for the purposes of the Protocol but remains to be a non-Annex I Party for the purposes of the Convention (UNFCCC 2019a).

Source: Asian Development Bank (Sustainable Development and Climate Change Department).

CDM is one of the project-based mechanisms under the Kyoto Protocol which is often referred in relation to Article 6.4 of the Paris Agreement (ADB 2018b; ADB 2019c). CDM dominates the region in both volume and number of projects. All countries in Group 1-except for Afghanistan, Kazakhstan, Kiribati, Samoa, and Solomon Islands-have registered CDM projects. Half of the countries have fewer than 10 registered CDM projects while India and the PRC alone represent $69.5 \%$ of total registered CDM projects as of February 2020 (UNFCCC 2020). 
JCM initiated by the Government of Japan, provides an example of a successful project-based bilateral offset crediting mechanism that can be considered a forerunner for cooperative approaches under Article 6.2 (ADB 2019a). Table 5 also shows that some countries have experience with JCM, an operational bilateral project-based mechanism, and that they have an understanding of carbon finance and solid technical experience (ADB 2018a). According to the JCM official website, Japan had signed bilateral agreements for cooperation on the JCM with 17 developing countries ${ }^{7}$ as of December 2019 (JCM n.d.). Of these 17 countries, 8 are ADB's DMCs from Group 1 that have shown interest in market mechanisms. Indonesia and Viet Nam have the largest number of registered JCM projects among DMCs (Appendix 3), and the majority of these projects are focused on energy efficiency and renewable energy (JCM n.d.).

Asia and the Pacific has substantial experience with project-based mitigation activities. While projectbased activities are likely to continue to be one part of the mitigation actions in post-2020 markets, there is a significant focus under the Paris Agreement, and Article 6, on upscaling mitigation actions and moving beyond projects and programs. As stated by the Climate Finance Innovators "the framing of international cooperation under the Paris regime reflects the desire of many Parties to give greater responsibility to the participating countries in designing their cooperative schemes, to move beyond the crediting of single mitigation projects to transformative and sector-based cooperation, and to redefine international cooperation as a tool to enhance mitigation ambition" (Greiner et al. 2019). Implementing upscaled approaches will be more challenging, and there is limited experience to reference from the pre2020 period. There were discussions on a New Market-Based Mechanism in the years following the Bali Action Plan that explicitly addressed upscaling to sectoral levels. ${ }^{8}$ However, this mechanism was never operationalized.

\subsection{Experience with Nationally Appropriate Mitigation Actions}

Nationally Appropriate Mitigation Actions (NAMAs), which were established under the Bali Action Plan, are another approach involving international support for mitigation actions that reduces $\mathrm{GHG}$ emissions in developing countries by national government initiatives "in the context of sustainable development, supported and enabled by technology, financing and capacity-building, in a measurable, reportable and verifiable manner" (UNFCCC 2008). NAMAs were not developed as carbon market instruments, although there have been discussions on NAMA crediting and several NAMAs were designed with carbon crediting in mind. For instance, credited NAMAs have been discussed as a way of scaling up carbon market mechanisms (Okubo et al. 2011). There is a distinction between domestic (unilateral) NAMAs and supported (multilateral) NAMAs based on the origin of support or financing used in developing and implementing the NAMAs.

The experience and engagement with multilateral NAMAs provide an indication of the interest of a government in initiating and developing upscaled activities that could be implemented with international support. Upscaling and transformational change, within one or across several sectors, are concepts that have emerged in the discussions following the release of the Bali Action Plan, and, as mentioned earlier, are now part of the framing of international cooperation under the Paris Agreement. NAMAs have also been brought forward as important vehicles for implementing NDCs (UNFCCC 2016).

7 The 17 countries are Bangladesh, Cambodia, Chile, Costa Rica, Ethiopia, Indonesia, Kenya, the Lao PDR, Maldives, Mexico, Mongolia, Myanmar, Palau, the Philippines, Saudi Arabia, Thailand, and Viet Nam.

8 The Bali Action Plan refers to Decision 1/CP.13 of the Report of the Conference of the Parties (of the UNFCCC) on its thirteenth session, held in Bali from 3 to 15 December 2007 (UNFCCC 2008). Upscaling to sectoral levels were mentioned later in other documents, including in Decision 1/CP.18 (FCCC/CP/2012/8/Add.1) paragraph 51(e). 
Many of the countries in this study have registered NAMAs for preparation and implementation support in the UNFCCC NAMA registry. In many cases, these proposals do not seem to have been funded and implemented. The NAMA database which contains updates up to 2017 shows that, of the 48 NAMAs listed under Group 1 countries, only 4 are being implemented and the remaining 44 are listed as "under development" (Ecofys 2017). Table 6 shows some examples of NAMAs supported under the program of the NAMA Facility funded by the governments of Denmark, Germany, and the United Kingdom, and the European Commission (NAMA Facility n.d.).

Table 6: Progress of Nationally Appropriate Mitigation Actions in India, Indonesia, and Thailand

\begin{tabular}{|l|l|l|}
\hline DMC & \multicolumn{1}{|c|}{ NAMA } & \multicolumn{1}{c|}{ Status } \\
\hline China, People's Republic of & Integrated Waste Management NAMA & Implementation \\
\hline India & Waste Solutions for a Circular Economy & Detailed preparation phase \\
\hline Indonesia & Sustainable Urban Transport Program & Implementation \\
\hline \multirow{2}{*}{ Mongolia } & $\begin{array}{l}\text { Mongolia - Energy Performance Contracting } \\
\text { for Residential Retrofitting in Ulaanbaatar City }\end{array}$ & Detailed preparation phase \\
\hline \multirow{2}{*}{ Thailand } & Refrigeration and Air Conditioning NAMA & Implementation \\
\cline { 2 - 3 } & Thai Rice NAMA & Implementation \\
\hline
\end{tabular}

$\mathrm{DMC}$ = developing member country, NAMA = nationally appropriate mitigation action.

Note:

a According to the NAMA Database, the Thai Rice NAMA Project is tagged as "under development" as of October 2017 (Ecofys 2017).

Source: NAMA Facility. n.d. Projects. https://www.nama-facility.org/projects/?tx_news_pi1[overwriteDemand][categories]=13,„\&no_ cache $=1$ (accessed 15 December 2019).

The experience with NAMA development and implementation shows that a great deal of preparatory work has been done in terms of developing NAMA concepts, planning for the measurement, reporting, and verification (MRV) of NAMA activities, designing the financial setup, and so forth. This is all useful experience that could assist countries in developing cooperative approaches under Article 6. However, it also shows that developing countries' attempts to attract international support for upscaled (sectoral) activities have been relatively limited under the NAMA approach. NAMAs are often designed to attract climate finance and are not private sector-driven to the same extent as the CDM, for example. If upscaled approaches under Article 6 could be designed to involve the private sector to a larger extent, maybe it could be more successful in gaining traction.

\subsection{Preparedness for a New Generation of Carbon Market Mechanisms}

While much expertise exists from the CDM and other project-based mechanisms, there is much less experience with the new and innovative types of cooperation envisaged by some countries under Article 6 (ADB 2018b). However, many countries have taken significant steps in designing their cooperative schemes and moving beyond the crediting of single mitigation projects to transformative and sector-based cooperation (Greiner et al. 2019). This preparation for international carbon markets could be understood in terms of directly preparing for the potential transfer of mitigation outcomes, or in terms of establishing domestic carbon pricing instruments that can later be linked with the international market. 


\section{International Initiatives on Market Mechanisms Leading Up to Preparations for Post-2020 Carbon Markets}

A number of international initiatives have been supporting DMCs to develop and implement market mechanisms that can enhance the countries' preparedness in participating in post-2020 carbon markets. Some of these initiatives are described in Table 7.

Table 7: Examples of International Initiatives that Support Country Preparations for Post-2020 Carbon Markets

\begin{tabular}{|c|c|c|}
\hline $\begin{array}{l}\text { International } \\
\text { Initiatives }\end{array}$ & Description & $\begin{array}{l}\text { Countries Supported } \\
\text { among Group } 1 \text { DMCs }\end{array}$ \\
\hline $\begin{array}{l}\text { Carbon Market } \\
\text { Program (CMP) }\end{array}$ & $\begin{array}{l}\text { CMP is one of ADB's initiatives on climate change mitigation } \\
\text { established in 2005. It supports DMCs to access carbon } \\
\text { finance through domestic and/or international carbon markets } \\
\text { to incentivize mitigation actions aligned with their NDCs under } \\
\text { the Paris Agreement, and to continue ADB's role in driving } \\
\text { sustainable development outcomes through carbon markets. } \\
\text { CMP consist of several fund and facilities that have been } \\
\text { providing carbon finance and technical capacity building to } \\
\text { project developers to participate in carbon markets from the } \\
\text { Kyoto Protocol era to post-2020 approaches under Article } 6 \\
\text { of the Paris Agreement. It includes Article } 6 \text { Support Facility } \\
\text { (A6SF), Future Carbon Fund (FCF), Japan Fund for Joint } \\
\text { Crediting Mechanism and Climate Action Catalyst Fund } \\
\text { among others. }\end{array}$ & $\begin{array}{l}\text { Bangladesh } \\
\text { China, People's Republic of } \\
\text { Fiji } \\
\text { India } \\
\text { Indonesia } \\
\text { Mongolia } \\
\text { Nepal } \\
\text { Pakistan } \\
\text { Thailand } \\
\text { Viet Nam }\end{array}$ \\
\hline $\begin{array}{l}\text { Collaborative } \\
\text { Instruments } \\
\text { for Ambitious } \\
\text { Climate Action } \\
(\mathrm{Cl}-\mathrm{ACA})^{\mathrm{a}}\end{array}$ & $\begin{array}{l}\text { Cl-ACA is an international voluntary initiative launched in } \\
\text { COP } 22 \text { in } 2016 \text { to support developing countries in developing } \\
\text { carbon pricing instruments in implementing their NDCs. } \\
\text { It was established through voluntary contribution of donors } \\
\text { from the Government of Germany, Norway, Sweden, } \\
\text { Switzerland, and Quebec. } \\
\text { Cl-ACA projects are implemented with assistance of } \\
\text { UNFCCC's Regional Collaboration Centres. } \\
\text { Types of carbon pricing instruments supported by Cl-ACA } \\
\text { include carbon tax, ETS, emission reduction funds, and hybrid } \\
\text { systems. }\end{array}$ & $\begin{array}{l}\text { Cambodia } \\
\text { Indonesia } \\
\text { Myanmar } \\
\text { Pakistan } \\
\text { Thailand } \\
\text { Viet Nam }\end{array}$ \\
\hline $\begin{array}{l}\text { Forest Carbon } \\
\text { Partnership } \\
\text { Facility }(F C P F)^{b}\end{array}$ & $\begin{array}{l}\text { FCPF is a global partnership of governments, businesses, civil } \\
\text { society, and Indigenous Peoples that was established in } 2008 . \\
\text { It is managed by the World Bank as a Trustee and Secretariat } \\
\text { with } 17 \text { donors. } \\
\text { It focuses on reducing emissions from deforestation and forest } \\
\text { degradation, forest carbon stock conservation, the sustainable } \\
\text { management of forests, and the enhancement of forest carbon } \\
\text { stocks in developing countries, activities commonly referred to } \\
\text { as REDD+. } \\
\text { The FCPF Carbon Fund pilots results-based payments to } \\
\text { countries that have advanced through REDD+ readiness } \\
\text { and implementation and have achieved verifiable emission } \\
\text { reductions in their forest and broader land-use sectors. }\end{array}$ & $\begin{array}{l}\text { Bhutan } \\
\text { Cambodia } \\
\text { Fiji } \\
\text { Indonesia } \\
\text { Lao PDR } \\
\text { Nepal } \\
\text { Pakistan } \\
\text { Thailand } \\
\text { Viet Nam }\end{array}$ \\
\hline
\end{tabular}


Table 7 continued

\begin{tabular}{|c|c|c|}
\hline $\begin{array}{l}\text { International } \\
\text { Initiatives }\end{array}$ & Description & $\begin{array}{l}\text { Countries Supported } \\
\text { among Group } 1 \text { DMCs }\end{array}$ \\
\hline $\begin{array}{l}\text { Partnership } \\
\text { for Market } \\
\text { Readiness (PMR) } \\
\text { and Partnership } \\
\text { for Market } \\
\text { Implementation } \\
(\text { PMI) }\end{array}$ & $\begin{array}{l}\text { PMR is a global partnership launched by the World Bank in } \\
2010 \text { to support countries in developing and implementing } \\
\text { climate mitigation policies including carbon pricing } \\
\text { instruments. } \\
\text { Under the technical work program, PMR focuses on three } \\
\text { carbon pricing tools-ETSs, carbon tax, crediting instruments, } \\
\text { and offsets. } \\
\text { PMI is PMR's successor program to help countries from } \\
\text { 'readiness' into 'implementation' of carbon pricing initiatives. }\end{array}$ & $\begin{array}{l}\text { China, People's Republic of } \\
\text { India } \\
\text { Indonesia } \\
\text { Kazakhstan } \\
\text { Thailand } \\
\text { Viet Nam }\end{array}$ \\
\hline $\begin{array}{l}\text { Transformative } \\
\text { Carbon Asset } \\
\text { Facility (TCAF) }\end{array}$ & $\begin{array}{l}\text { TCAF is an international finance facility, launched in } 2015 \text { to } \\
\text { pilot innovative and results-based carbon market mechanism } \\
\text { under Article } 6 \text { of the Paris Agreement. } \\
\text { TCAF helps in shaping international carbon markets for } \\
\text { the post-Kyoto era, and supports developing countries to } \\
\text { implement market-based carbon pricing and sector-wide } \\
\text { mitigation measures. } \\
\text { It was jointly launched by Canada, Germany, Norway, Sweden, } \\
\text { Switzerland, the United Kingdom, and the World Bank. }\end{array}$ & $\begin{array}{l}\text { India } \\
\text { Indonesia }\end{array}$ \\
\hline
\end{tabular}

COP = Conference of the Parties, DMC = developing member country, ETS = emission trading system, Lao PDR = Lao People's Democratic Republic, NDC = nationally determined contribution, REDD + = reducing emissions from deforestation and forest degradation, and foster conservation, sustainable management of forests, and enhancement of forest carbon stocks, UNFCCC = United Nations Framework Convention on Climate Change.

Notes:

1. Group 1 comprises 20 developing member countries of ADB that expressed their intent or consideration of using market mechanisms in their NDCs.

2. The table lists Group 1 DMCs known to have taken part or are participating in the initiative based on publicly available information.

a United Nations Framework Convention on Climate Change (UNFCCC) n.d.f. The Collaborative Instruments for Ambitious Climate Action (Cl-ACA) Initiative. https://unfccc.int/about-us/regional-collaboration-centres/the-collaborative-instrumentsfor-ambitious-climate-action-ci-aca-initiative.

b Forest Carbon Partnership Facility (FCPF). n.d. https://forestcarbonpartnership.org/.

c Partnership for Market Readiness (PMR) n.d. Implementing Country Participants. https://www.thepmr.org/pmrimplements/0 (accessed 15 November 2019); PMR 2019a. Annual Report 2019: From Readiness to Implementation.

d Transformative Carbon Asset Facility (TCAF). n.d. https://tcaf.worldbank.org/about-us.

Source: Asian Development Bank (Sustainable Development and Climate Change Department).

Carbon Market Program. The Carbon Market Program (CMP) was initially established to provide support to GHG mitigation activities in developing countries and build capacity to participate in carbon markets under the Kyoto Protocol through the Asia Pacific Carbon Fund, the Future Carbon Fund and the Technical Support Facility. CMP's support has then expanded to include assistance with domestic carbon pricing and emissions trading schemes, bilateral crediting mechanisms with the establishment of Japan Fund for the Joint Crediting Mechanism and market-based approaches under Article 6 of the Paris Agreement. Current components of CMP are focused on supporting countries to access carbon finance through domestic and/or international carbon markets to incentivize mitigation actions aligned with their NDCs, and continue to drive sustainable development outcomes through carbon markets. Programs such as the Article 6 Support Facility, the Climate Action Catalyst Fund, and another in the pipeline - the Credit Marketing Facility, will be providing technical support in developing mitigation actions and undertaking robust accounting under cooperative approaches of Article 6, as well as co-financing support for implementing upscaled mitigation actions. 
Collaborative Instruments for Ambitious Climate Action. The Collaborative Instruments for Ambitious Climate Action (Cl-ACA) is coordinated by the UNFCCC and supports Parties in developing carbon pricing instruments to implement NDCs by "building on existing NDC support projects, promoting awareness of carbon pricing, and exploring possibilities to participate in carbon markets" (UNFCCC n.d.f). It was launched in the 22nd Conference of the Parties (COP 22) to support developing countries by voluntary contribution of donors from the Government of Germany, Norway, Sweden, Switzerland, and Quebec. ClACA projects are implemented with the assistance of UNFCCC's Regional Collaboration Centres. Cl-ACA supports countries in establishing carbon tax, ETS, emission reduction funds, and hybrid systems. DMCs in Southeast Asia that are considering to use market mechanisms, such as Cambodia, Indonesia, the Lao PDR, Myanmar, Thailand, and Viet Nam, have been involved in a Cl-ACA study on cooperative MRV as a foundation for a potential regional carbon market within the Association of Southeast Asian Nations (ASEAN) (UNFCCC 2019b). Aside from ASEAN member countries, Pakistan is also working with Cl-ACA to explore the use of carbon pricing instruments in the country (UNFCCC n.d.f).

Forest Carbon Partnership Facility. There are also other multilateral initiatives contributing to preparatory work on market mechanisms that are focused on reducing emissions from deforestation and forest degradation, and foster conservation, sustainable management of forests, and enhancement of forest carbon stocks (REDD+). One example is the Forest Carbon Partnership Facility (FCPF), which supports REDD+ through two funds: the FCPF Readiness Fund and the FCPF Carbon Fund (FCPF n.d). The FCPF Readiness Fund helps countries set up the building blocks to implement REDD+, including designing national REDD+ strategies, developing reference emission levels, designing MRV systems, and setting up national REDD+ management arrangements. The FCPF Carbon Fund pilots incentive payments for REDD + efforts that are done in accordance with negotiated contracts for verifiable emission reductions. The FCPF Carbon Fund payments are designed to help countries and their stakeholders achieve long-term sustainability in financing forest conservation. Although FPCF is focused on REDD+, they build capacities of countries in data collection, MRV, and transacting using emission reductions, all of which will be relevant and useful for implementing market-based approaches under Article 6.

Partnership for Market Readiness and Partnership for Market Implementation. The Partnership for Market Readiness (PMR) provides comprehensive support to countries in terms of readiness and capacity building in developing and implementing carbon pricing instruments. Among the DMCs that are considering or intending to use market mechanisms in accomplishing NDCs, six are participating in the PMR, where five DMCs - India, Indonesia, the PRC, Thailand, and Viet Nam, are "implementing country participants," while one DMC-Kazakhstan—is a "technical partner" (PMR 2019a). The PMR supports these "implementing country participants" in developing and finalizing "market readiness proposals" (MRPs) which become a roadmap for planning and designing their carbon pricing instruments including the development of greenhouse gas (GHG) baselines and MRV systems. For countries ready to design and implement a carbon pricing instrument, the PMR provides a platform for pilot testing (PMR n.d.). For "technical partners," PMR supports countries on technical aspects of implementing MRP activities with a focus on enhancing three carbon pricing tools (ETSs, carbon tax, and crediting instruments). The PMR Secretariat will be finalizing its country readiness programs by the end of 2020 , and transition into supporting countries from "readiness" into "implementation" of carbon pricing instruments (PMR 2019a) through PMR's successor program, the Partnership for Market Implementation (PMI) which will launch in July 2020 (PMR 2019d). PMl's support to 30 countries include development and implementation of carbon pricing instruments to meet NDC targets and enabling countries' participation in the operationalization of Article 6 of the Paris Agreement.

Transformative Carbon Asset Facility. The Transformative Carbon Asset Facility (TCAF) is an "international finance facility piloting innovative, results-based carbon market mechanism under Article 6." (TCAF n.d.) At the national level, TCAF helps countries adopt market-based carbon pricing, implement sectoral mitigation measures, and create favorable conditions to encourage private sector 
investments for mitigation actions. At the international level, TCAF helps shape post-2020 international carbon markets by testing transfer of mitigation outcomes and use of robust accounting methods.

Other initiatives. There are many other initiatives that support countries in preparing for participation in new generation carbon markets including the Carbon Pricing Leadership Coalition, the Networked Carbon Markets, and the Carbon Initiative for Development (Ci-Dev) -all established by the World Bank (World Bank 2019a) - as well as the Global Carbon Market Project funded by the German Federal Ministry for the Environment, Nature Conservation, and Nuclear Safety (BMU) (GIZ n.d.).

\section{Countries' Preparedness for New Market Mechanisms}

This paper examined the participation of DMCs in the abovementioned international initiatives together with the countries' ongoing work on domestic market-based instruments to consider their preparedness for post-2020 carbon markets. Table 8 roughly categorizes Group 1 DMCs, or those considering or intending to use market mechanisms in their NDCs, according to the level of their experience and possible preparedness in accessing new carbon markets. However, it should be noted that these countries could be doing other preparatory work that may not have been publicly available yet at the time of publishing this paper.

Table 8: Preparedness of Group 1 Countries for Post-2020 Carbon Markets

\begin{tabular}{|c|c|c|c|}
\hline $\begin{array}{l}\text { Level of } \\
\text { Preparedness }\end{array}$ & DMC & $\begin{array}{c}\text { Participation in International } \\
\text { Initiatives }\end{array}$ & $\begin{array}{l}\text { Experience with } \\
\text { Domestic MBls }\end{array}$ \\
\hline \multirow{14}{*}{ Limited } & Afghanistan & - & - \\
\hline & Armenia & - & - \\
\hline & Bangladesh & - & - \\
\hline & Bhutan & FCPF & - \\
\hline & Cambodia & $\mathrm{Cl}-\mathrm{ACA}, \mathrm{FCPF}$ & - \\
\hline & Fiji & FCPF & - \\
\hline & Kiribati & - & - \\
\hline & Lao PDR & $\begin{array}{l}\text { FCPF, Ci-Dev } \\
\text { Yes }\end{array}$ & - \\
\hline & Mongolia & SEA virtual piloting & - \\
\hline & Myanmar & $\mathrm{Cl}-\mathrm{ACA}$ & - \\
\hline & Nepal & FCPF & - \\
\hline & Pakistan & $\mathrm{Cl}-\mathrm{ACA}, \mathrm{FCPF}$ & - \\
\hline & Samoa & - & - \\
\hline & Solomon Islands & - & - \\
\hline \multirow{2}{*}{ Moderate } & Indonesia & $\mathrm{Cl}-\mathrm{ACA}, \mathrm{FCPF}, \mathrm{PMR}, \mathrm{TCAF}$ & ETS (considered) \\
\hline & Viet Nam & $\mathrm{Cl}-\mathrm{ACA}, \mathrm{FCPF}, \mathrm{PMR}$ & ETS (considered) \\
\hline
\end{tabular}


Table 8 continued

\begin{tabular}{|l|l|l|l|}
\hline $\begin{array}{l}\text { Level of } \\
\text { Preparedness }\end{array}$ & \multicolumn{1}{|c|}{ DMC } & \multicolumn{1}{|c|}{$\begin{array}{r}\text { Participation in International } \\
\text { Initiatives }\end{array}$} & $\begin{array}{r}\text { Experience with } \\
\text { Domestic MBls } \mathbf{s}^{\mathrm{a}}\end{array}$ \\
\hline \multirow{4}{*}{ Advanced } & $\begin{array}{l}\text { China, People's } \\
\text { Republic of }\end{array}$ & PMR & $\begin{array}{l}\text { ETS (scheduled for } \\
\text { implementation) }\end{array}$ \\
\cline { 2 - 5 } & India & PMR, TCAF & PAT; REC \\
\cline { 2 - 5 } & Kazakhstan & PMR & ETS (in force) \\
\cline { 2 - 5 } & Thailand & Cl-ACA, FCPF, PMR & $\begin{array}{l}\text { Mandatory ETS (considered); } \\
\text { T-COP; T-VER }\end{array}$ \\
\hline
\end{tabular}

$(-)=$ No information or the country is not engaged in the international or domestic initiatives related to market mechanisms, $\mathrm{Ci}-\mathrm{Dev}=$ Carbon Initiative for Development, $\mathrm{Cl}-\mathrm{ACA}=$ Collaborative Instruments for Ambitious Climate Action, ETS = emissions trading system, FCPF = Forest Carbon Partnership Facility, Lao PDR = Lao People's Democratic Republic, MBI = market-based instrument, PMR = Partnership for Market Readiness, TCAF = Transformative Carbon Asset Facility, SEA = Swedish Energy Agency, REC $=$ Renewable Energy Certificate, $\mathrm{T}-\mathrm{COP}=$ Thailand Carbon Offset Process, $\mathrm{T}-\mathrm{VER}=$ Thailand Voluntary Emission Reduction Program.

Notes:

1. Group 1 comprises 20 developing member countries of ADB that expressed their intent or consideration of using market mechanisms in their NDCs.

2. The table lists preparatory activities of DMCs based on publicly available information.

a The term 'considered' is used if the government announced to work towards the implementation of carbon pricing initiatives and this has been formally confirmed by official government sources. The term 'scheduled for implementation' is used once the ETS has been formally adopted through legislation and have an official and planned start date.

b The PRC launched its regional ETS in 2013 and announced the plan to launch national ETS in 2017. The national ETS is currently scheduled to be implemented in 2020 once the trading of emissions reductions will take place. Obtained from various sources: Government of the People's Republic of China, National Development and Reform Commission. 2017. Work Plan for Construction of the National Emissions Trading System (Power Sector). No. 2191. http://www.ndrc.gov.cn/zcfb/gfxwj/201712/ W020171220566893899825.pdf; Organisation for Economic Co-operation and Development (OECD). 2018. Supplement to Effective Carbon Rates: People's Republic of China. https://www.oecd.org/tax/tax-policy/effective-carbon-rates-china.pdf; and, GIZ and the Government of the People's Republic of China, Ministry of Ecology and Environment. ETS in China. https://ets-china. org/about-us/.

Source: Asian Development Bank (Sustainable Development and Climate Change Department); For ETS: International Carbon Action Partnership (ICAP). 2019b. Emissions Trading Worldwide: Status Report 2019. Berlin, Germany. https://icapcarbonaction. com/en/?option=com_attach\&task=download\&id=625.

As presented in Table 8, to date, a majority of the DMCs in Group 1 have relatively limited experience in domestic carbon pricing instruments. Their level of engagement in international initiatives like PMR is also not extensive. Some countries participate in FCPF (Bhutan, Cambodia, Fiji, Lao PDR, Nepal, and Pakistan) or in $\mathrm{Cl}-\mathrm{ACA}$ (Cambodia, Myanmar, and Pakistan). Bhutan has been discussing with the World Bank the possibility of developing and piloting a Bhutan Climate Fund (BCF) to help monetize mitigation outcomes from hydropower exports (World Bank 2018b). The Swedish Energy Agency has funded studies in the form of virtual pilots of Article 6 in several countries, including Mongolia and the Philippines (NICA 2019). The World Bank's Ci-Dev is also planning a project with the objective of enhancing energy efficiency in cook stoves and reducing carbon emissions from households across three provinces in the Lao PDR (World Bank 2019c). The project is being implemented as a results-based finance, public-private partnership that links public support to the achievement of demonstrated benefits, which in turn mobilizes private sector investments. Even though there is no specific mention of Article 6 in the project document, a specific reference to post-2020 carbon finance could imply implementation under Article 6.

Two countries could be considered to be relatively progressive in their preparations for new markets given their consideration of using market-based instruments (MBIs) and establishing ETSs in their countries: Indonesia and Viet Nam. 
Indonesia. Indonesia, with support from the PMR, is considering carbon pricing or market-based instruments, including a national ETS, for the power and industry sectors as part of meeting its NDC targets (ICAP 2019b; PMR n.d.). In 2017, Indonesia mandated the use of economic instruments, including carbon pricing instruments, by issuing Government Regulation No. 46/2017 on Environmental Economic Instruments. This regulation provides the policy basis for MBIs and for the establishment of an ETS before 2024 (ICAP 2019d). The link of Indonesia's planned ETS with international markets are not known at this stage. As part of the PMR, the country has been developing foundations of the carbon market and is studying the possibility of using MBls for the cost-effective delivery of real, additional, and permanent emissions reduction. Indonesia is preparing a voluntary ETS, and piloting of carbon offsetting mechanism as part of options of MBls (PMR 2019c). In addition, the Ministry of Environment and Forestry of Indonesia is working on the development of a domestic crediting mechanism as part of the PMR support (Government of Indonesia n.d.). This mechanism is an appreciation scheme where an appreciation certificate, known as the Indonesia Certified Emission Reduction (ICER), will be issued to participating stakeholders to encourage involvement of the public and private sectors in mitigating GHG emissions (PMR 2019b). Parallel discussions on generating demand for the ICERs are being conducted as well. For this crediting mechanism, relevant guidelines and methodologies have been developed with support from PMR and were tested on a pilot project during 2019 (PMR 2019c). Aside from working with PMR, Indonesia is also reportedly being supported by TCAF in its attempt to address emissions from the municipal waste sector (Spalding-Fecher 2018).

Viet Nam. Viet Nam is considering an ETS for the steel sector and MBls for the waste sector starting in 2020. Viet Nam's NDC and its Plan for the Implementation of the Paris Agreement (PIPA), which was approved in 2016, mentioned market instruments and carbon markets as part of mitigation measures. As part of the PMR, Viet Nam aims to develop MBIs in two phases by (i) establishing the legal framework and pilot MBIs in selected sectors/regions (Phase 1: 2013-2018), and (ii) establishing a domestic carbon market with possible links with the international market (Phase 2: 2018-2020) (PMR n.d.).

Viet Nam is analyzing options for carbon pricing approaches suitable for the country and is developing pilot crediting programs in the steel and waste sectors that may start after 2020 (World Bank 2019d). There are also different studies looking into potential carbon pricing initiatives including a study financed by the United Nations Development Programme and the United States Agency for International Development (Michaelowa et al. 2018). This study examined tax instruments such as the environmental protection tax on the use of fuels (oil and coal) and the two potential instruments related to payment for forest ecosystem services and payment for environmental protection fees for waste treatment and management.

The remaining four countries under Group 1-India, Kazakhstan, the PRC, and Thailand-are seen to be more advanced than many countries in Group 1 as they are already implementing domestic marketbased instruments, including ETSs.

India. India has been implementing domestic market-based instruments such as the Perform, Achieve, and Trade (PAT) system since 2012, and the Renewable Energy Certificate (REC) system since 2011. The PAT system is similar to an ETS, but it does not set an absolute cap for emissions like the cap-and-trade system of ETSs (EDF et al. 2015). Instead, the PAT system sets intensity-based energy targets. India also uses the REC trading system, which is a non-ETS, market-based mechanism for climate mitigation. Additionally, as part of its PMR activities, India is working on a road map for carbon pricing instruments in the waste and micro, small, and medium-sized enterprise (MSME) sectors, including pilot testing. The country is also being supported by the Germany-funded project, Global Carbon Market, on the use of new carbon market instruments for implementing its national climate change action plan and the NDC, as well as in engaging discussions with public and private sector decision makers on Article 6 of the Paris Agreement (GIZ n.d.). There are also indications that India takes part in the TCAF, where an energy efficiency program for household appliances in Indian cities seem to be under serious consideration (Greiner et al. 2019). 
Another initiative that indicates the participation of India is the World Bank Warehouse Facility initiative. This initiative, which began operating in 2019, provides infrastructure for early action through the creation of mitigation outcomes linked to multilateral development banks' operations, which will test independent assessment process and initiate discussions in countries on NDCs and internationally transferred mitigation outcomes (ITMOs). Relevant World Bank Warehouse Facility programs in India include grid-connected solar rooftops and shared infrastructure for solar parks (World Bank 2019b).

Kazakhstan. Kazakhstan launched its ETS (referred to as Kazakh ETS or KAZ ETS) in January 2013 as the first cap-and-trade system in Asia that resembles European Union's ETS in its design (ADB 2015). The Kazakh ETS was introduced in 2011 through an amendment to the country's Environmental Code. The system was temporarily suspended in 2016-2017 to improve the MRV system and GHG emissions regulations, but has restarted since 1 January 2018 with new trading procedures (ICAP 2019b). The development and operationalization of the domestic offset program is among the challenges facing the Kazakh ETS and will be key to the success of the system (PMR n.d.). As there are no methodologies, tools, or guidelines for project development, Kazakhstan is working with Norway and the United States to develop offset protocols (PMR n.d.). For MRV, 40 sectoral guidelines for $\mathrm{GHG}$ monitoring and reporting have been developed, but more work is needed to develop a verification framework (PMR n.d). The Kazakh ETS is focused on domestic offsets, but international credits may be allowed in the future (ICAP 2019e). It is not fully clear if the national ETS will be linked with the international carbon market, though in its NDC, Kazakhstan mentioned that the country "will consider adequately discounting international units for compliance to ensure a contribution to net global emissions reduction" (Government of Kazakhstan 2016). This could imply an implicit link of its national ETS to the international carbon market.

People's Republic of China. The PRC approved the ETS pilots in seven regions (five provinces and two cities) in 2011 and launched them in 2013 and 2014 (PMR n.d.). The National Development and Reform Commission (NDRC) announced the plan for launching the national ETS in December 2017. ${ }^{9}$ The launch of the PRC's national ETS and provisions for its development was laid out in the Work Plan for Construction of the National ETS for the Power Sector that was approved in 2017 (Government of the People's Republic of China 2017). As the country is currently focusing on operationalizing the national ETS, it is not clear at this stage if it will be linked with other ETSs or international market mechanisms. Once the national ETS is fully operational, a potential link with other systems could be explored (ICAP 2019d). MRV guidelines and verification guidelines are available for the eight sectors that will be covered by the ETS. Currently, the PRC's ETS covers the power sector, but it is expected to cover seven other sectors including petrochemicals, chemicals, building materials, steel, nonferrous metals, paper, and domestic aviation.

Thailand. Thailand is operating a voluntary ETS and is exploring the possibility of developing a mandatory ETS (ICAP 2019b; PMR n.d.). In its NDC, Thailand specified interest in exploring the potentials of bilateral, regional, and international market mechanisms. Currently, it is developing a legal framework and road map for ETS. An MRV system and guidelines for the Thailand Voluntary Emissions Trading Scheme (Thailand V-ETS) were developed during 2013-2016. Thailand V-ETS pilots were tested in two phases, the first one starting from 2014-2017 to test the MRV system and develop sector-specific MRV guidelines. The second phase of pilots started in 2018 and will continue up to 2020 to test the registry and trading platform. In addition to Thailand V-ETS, Thailand is also operating the Thailand Carbon Offset Process (T-COP) and Thailand Voluntary Emission Reduction Program (T-VER), both of which were set up in 2013. T-COP is a voluntary carbon offset program where individuals and organizations can use carbon footprint tools to calculate their emissions ( $T G O$ n.d.). T-VER is another voluntary GHG emission reduction program where trade of carbon credits is mainly used for corporate social responsibility (TGO 2014). As many of the initiatives in the carbon market in Thailand are voluntary, one challenge will

9 This announcement has been cited differently as a 'political launch', official launch or plan to launch the national ETS. 
be to introduce mandatory systems. Cooperative approaches under Article 6.2 could perhaps support the introduction of such schemes by contributing to funding and linking with international sources of demand. Thailand could also be involved in piloting under Article 6 as it has developed a proposal for the Climate Cent Foundation (CCF) in Switzerland that is aimed at developing an electric vehicle fleet in Thailand, which could be developed into an Article 6 pilot project (Greiner et al. 2019).

More details on the ETSs of the 5 countries-Indonesia, Kazakhstan, the PRC, Thailand, and Viet $\mathrm{Nam}$-are provided in Appendix 2. With their experience from, and capacity for managing emissions trading, Kazakhstan and the PRC could link their ETSs directly or indirectly with other systems when and if they are ready and interested in such linkage. Indonesia, Thailand, and Viet Nam have less experience with ETSs compared to Kazakhstan and the PRC. Linking ETSs with international carbon markets could form part of the implementation of cooperative approaches under Article 6 and would allow the flow of credits between countries to benefit from access to each other's mitigation opportunities. However, linking ETSs will require careful harmonization of system design, including MRV standards, eligibility of offsets, price, and stringency of the cap that can be better harmonized if systems are designed to be linked from the early stage of development (ADB 2015). Hence, development of national carbon pricing instruments like the ETS can play an important role in enhancing countries' preparedness in accessing new market mechanisms under Article 6 of the Paris Agreement. Ongoing work on developing the ETS is therefore a valuable source of capacity building for Article 6 activities.

Amidst the discussion on the readiness of some countries in international linkage of domestic systems such as ETS, it should be noted though that to date, these countries have not been clear yet in their positions about pursuing such linkages as part of their climate actions. It is hypothesized that once the rules and guidelines for international carbon market and for implementation under Article 6 are clarified, more countries would be ready to determine their positions as to how to navigate their domestic carbon pricing policies and if they will link their ETSs with international carbon markets.

As a final note, discussions on preparedness of countries for implementing Article 6 would not be complete without touching the topic of MRV. A discussion on relative capacity and experience in MRV is provided in Appendix 4, which shows that readiness in terms of transparency and reporting vary among the DMCs in this study. This may affect a country's ability to participate in Article 6 or limit its opportunity to choose between Articles 6.2 and 6.4. It should also be noted that while the general provisions for transparency and reporting in the Paris Agreement was adopted during the 24th Conference of the Parties (COP 24) in Katowice (UNFCCC 2019d), the specific guidance and rules relating to MRV, reporting and review under Article 6 is part of the pending Article 6 decision, which now has been deferred to COP 26. 


\section{CONCLUSION}

As of December 2019, 184 countries have submitted their nationally determined contributions (NDCs) under the Paris Agreement, pledging to reduce greenhouse (GHG) emissions and identifying needs for adaptation and mitigation actions. NDCs are the cornerstone of the Paris Agreement and an important signal of political commitment, but the current level of collective ambitions expressed in NDCs are insufficient to achieve the Paris Agreement's goals. It is still technically possible to restrict global warming to below 2.0 degrees Celsius $\left({ }^{\circ} \mathrm{C}\right.$ ) or even $1.5^{\circ} \mathrm{C}$, as targeted in the Paris Agreement, but only if countries significantly ratchet up their ambitions and take action to achieve these ambitions.

Market mechanisms under the framework of Article 6 are one of the most promising and important instruments for incentivizing enhanced ambition by channeling much needed finance to support mitigation action and stimulate private sector involvement. Market-based mechanisms are not new but need to evolve from simply being off-setting mechanisms to deliver cost-efficient, real reductions in global emissions while allowing countries to access carbon finance to facilitate mitigation actions aligned with their NDCs.

Developing countries in Asia and the Pacific accounted for $43.1 \%$ of global greenhouse (GHG) emissions in 2018, and this share continues to grow, meaning their ability and willingness to raise ambitions and reduce GHG emissions is critical. This paper has analyzed the NDCs of 41 developing member countries (DMCs) of the Asian Development Bank (ADB) in Asia and the Pacific to understand their intent and preparedness to use market mechanisms in achieving targets set out in their NDCs and potentially raising ambition over time. It finds that of these $41 \mathrm{DMCs}, 20$ have specified their intention to use, or are considering using market mechanisms in achieving their NDCs-referred to as (Group 1). ${ }^{10}$ The following paragraphs present other key findings of this analysis:

Intent to use market mechanisms. The Group 1 countries account for more than $95 \%$ of the total GHG emissions of 15.2 gigatons of carbon dioxide (GtCO2e) attributable to ADB's 41 DMCs in Asia and the Pacific. This shows the non-uniform distribution of regional GHG emissions. More importantly, these large emitters that account for the majority share of emissions in the region are inclined to use market mechanisms in pursuing targets articulated under their respective NDCs.

Use of market mechanisms in achieving NDC targets. While these 20 Group 1 countries have signaled intent to use market mechanisms, it is not entirely clear how these countries will implement this intent. NDCs are high-level political documents and, in most cases, do not elaborate on how targets will be achieved. Some of the NDCs specify the type of international support needed to achieve the conditional targets but, typically, NDCs do not show how the use of market mechanisms will contribute to mitigation targets for specific sectors.

Experience with pre-2020 market mechanisms. The countries that account for most of the GHG emissions in Asia and the Pacific (Group 1) are not only inclined to use market mechanisms in achieving NDC targets, but also have extensive, albeit varied, experience in international and bilateral market mechanisms such as the Clean Development Mechanism (CDM) and the Joint Crediting Mechanism (JCM). It is pertinent to note that such countries represent $78 \%$ of all registered CDM projects in the world, and $80 \%$ of all registered JCM projects hosted in 17 partner countries under JCM. These countries can consequentially build upon this extensive experience and expertise to engage in new market mechanisms.

10 Afghanistan, Armenia, Bangladesh, Bhutan, Cambodia, Fiji, India, Indonesia, Kazakhstan, Kiribati, Lao People's Democratic Republic, Mongolia, Myanmar, Nepal, Pakistan, People's Republic of China, Samoa, Solomon Islands, Thailand and Viet Nam 
Preparedness for post-2020 carbon market. Many of these 20 Group 1 countries are already working with international partners to enhance their preparedness to access the new generation of carbon markets. Some of these countries are taking significant steps by engaging in multiple international initiatives on market mechanisms while others are focusing more on establishing domestic carbon pricing instruments that can potentially be linked with international carbon markets. Some of the countries are exploring a generalized use of market mechanisms while others are linking their use of market mechanisms to specific sectors.

This paper has shown that many of ADB's DMCs in Asia and the Pacific (i) intend to use market mechanisms in achieving their NDCs, (ii) have the relevant experience and expertise in using different types of market mechanisms, and (iii) are preparing well for post-2020 carbon markets. How countries will use market mechanisms to accomplish NDCs targets is still to be determined and DMCs have a range of options to choose from when engaging in Article 6 and new market mechanisms for their participation in post 2020 carbon markets.

For ADB's DMCs, the Paris Agreement represents an important evolution in climate politics as they have an obligation to define, report on, and account for their NDCs. DMCs are working hard to operationalize their NDCs and be active participants in the operationalization of the Paris Agreement. DMCs that account for most of the GHG emissions in Asia and the Pacific are ready and willing to use market mechanisms to achieve their NDC ambitions. However, countries in the region need varied degrees of capacity building, technical, and policy development support to help them in setting up institutional arrangements to facilitate their participation in post-2020 carbon markets. 
ᄒ

这

눈

范

$+$

อ

40

는

농 종

통 음

$\sum^{0} \mathbf{Z}$

200. 항

등 둔

을 든

ชั

ด

+

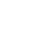

웅

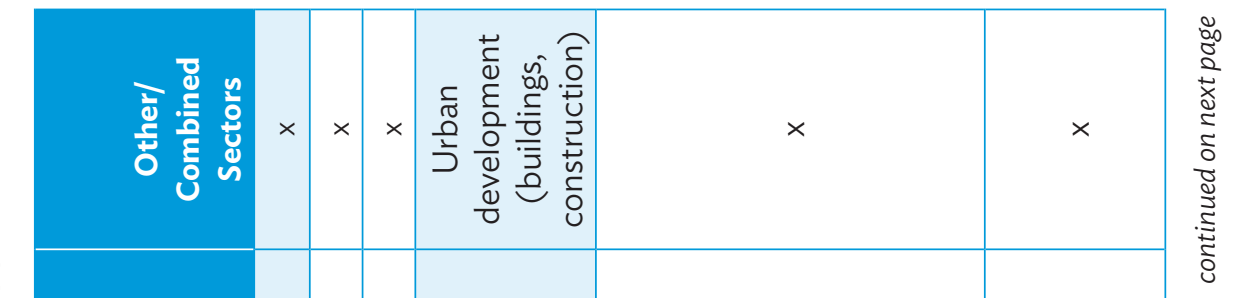

0

n?

to

कํำ ह

들

은

艺

ஸे

0 는

단

त $\sum$ 它

은

○ व

zั

这

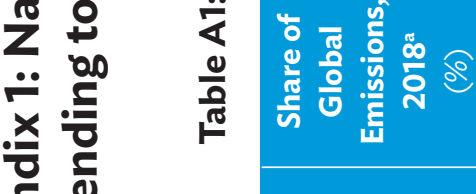

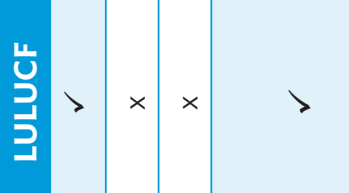

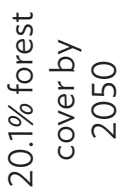

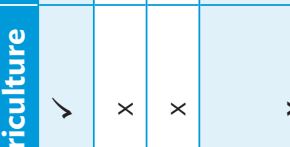

$\frac{0}{\rho}=>x>$

$\frac{5}{2}>x$

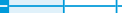

需

容

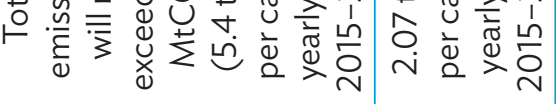

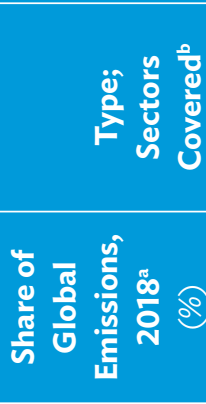

吾 $\frac{1}{1}$

बे

帘

ปั

๘

๙ิ

$\stackrel{0}{0}$

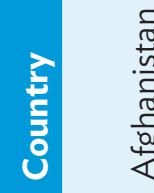

$\frac{. \frac{\pi}{5}}{\frac{1}{6}}$ 


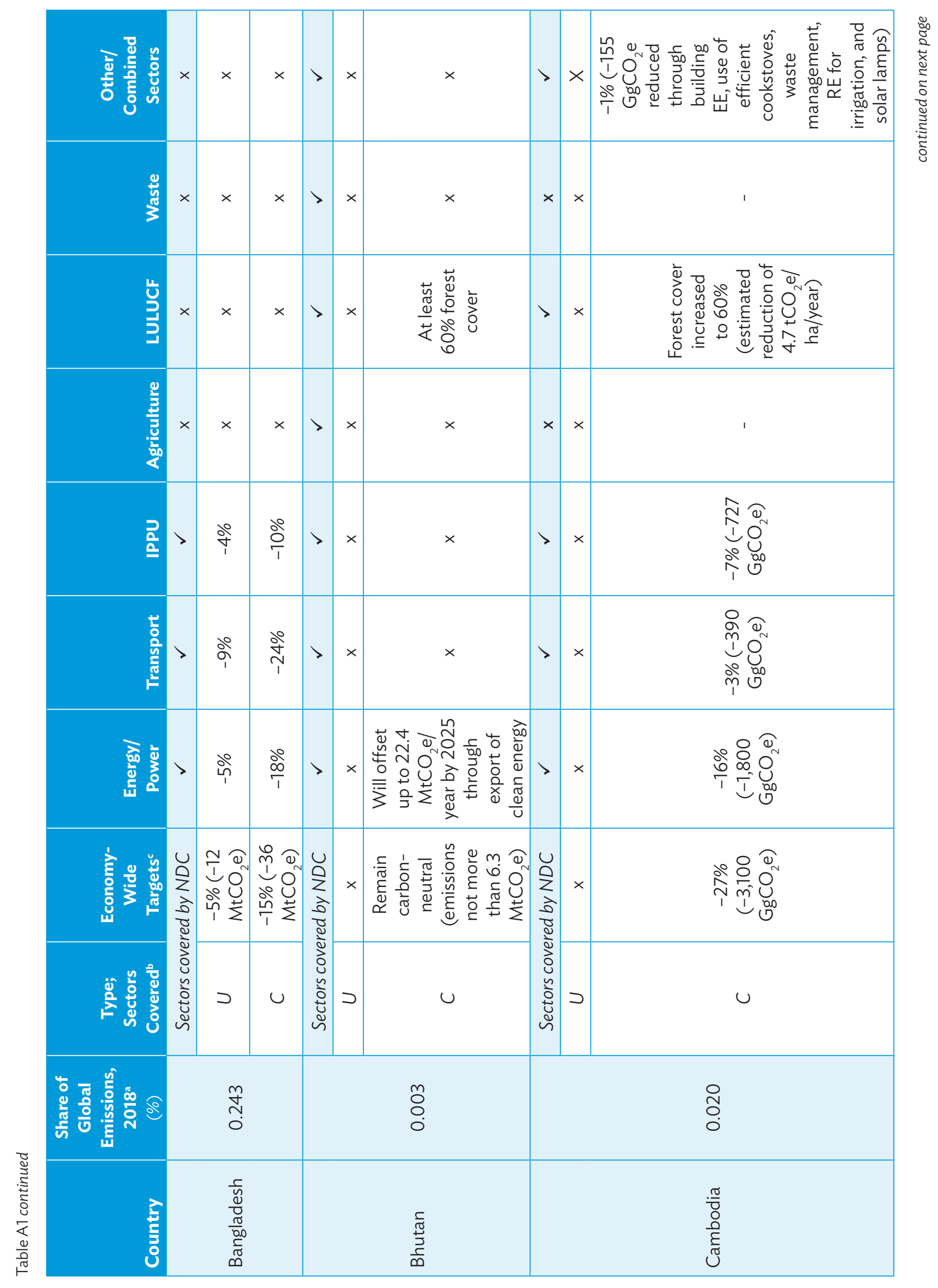




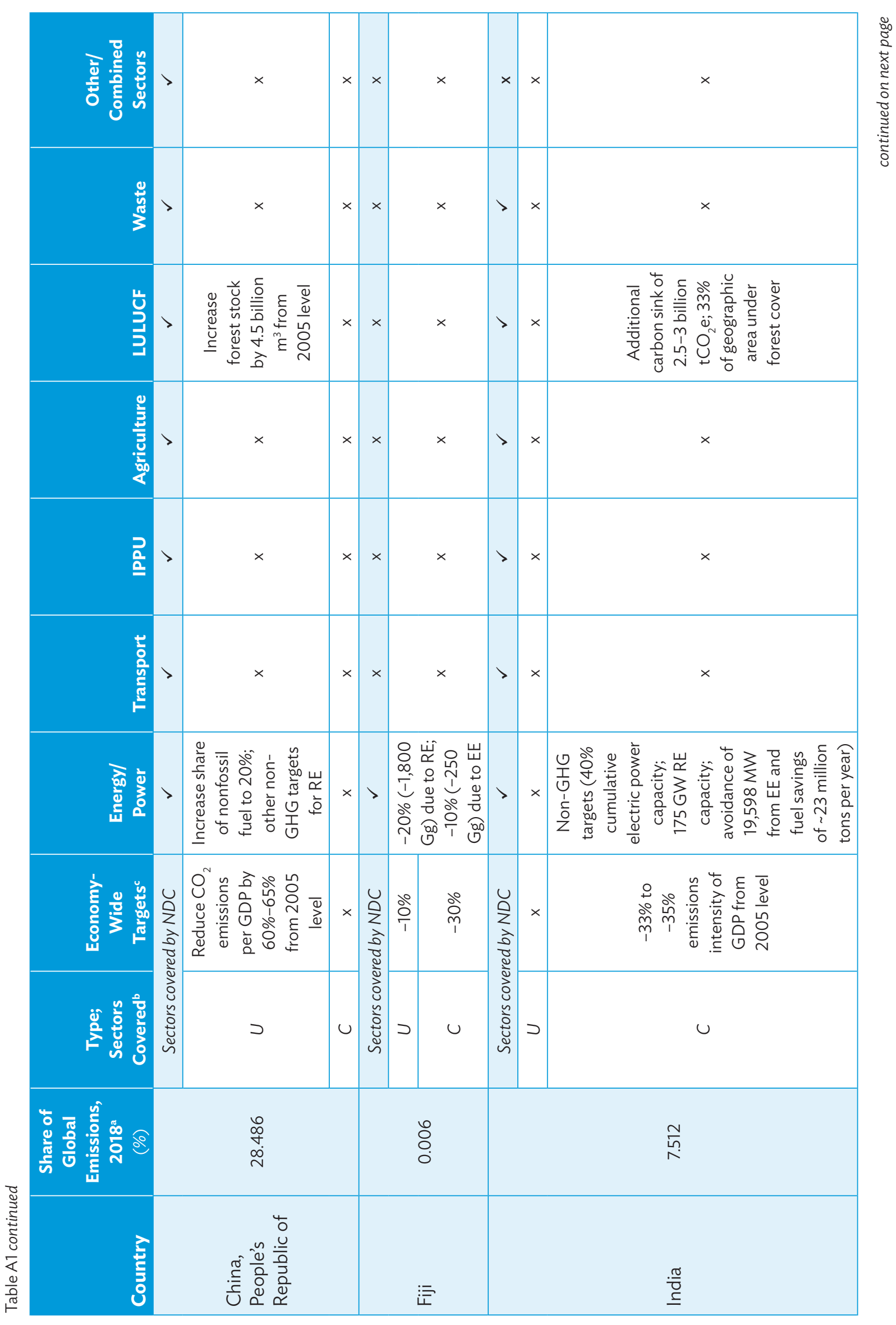




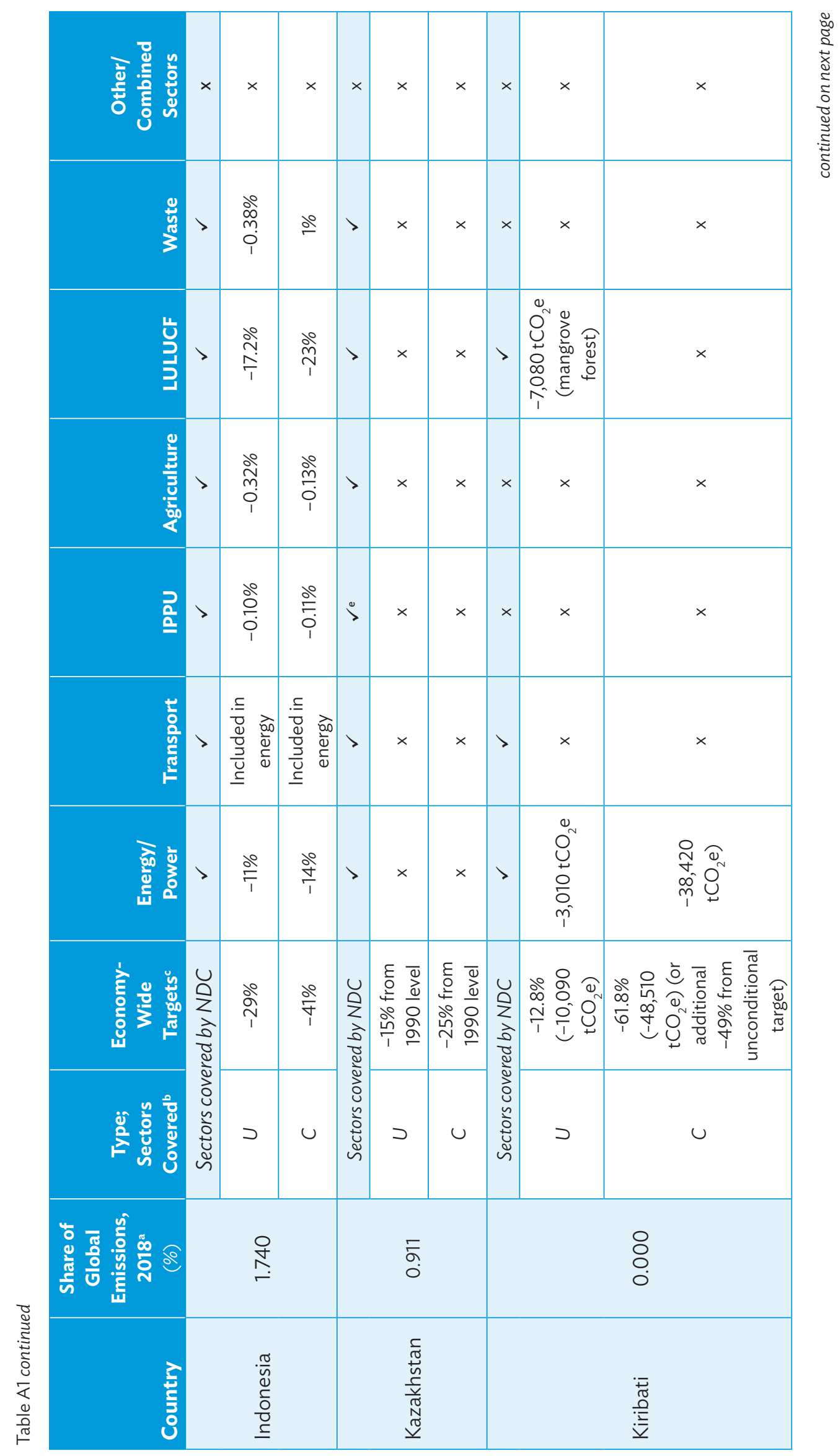




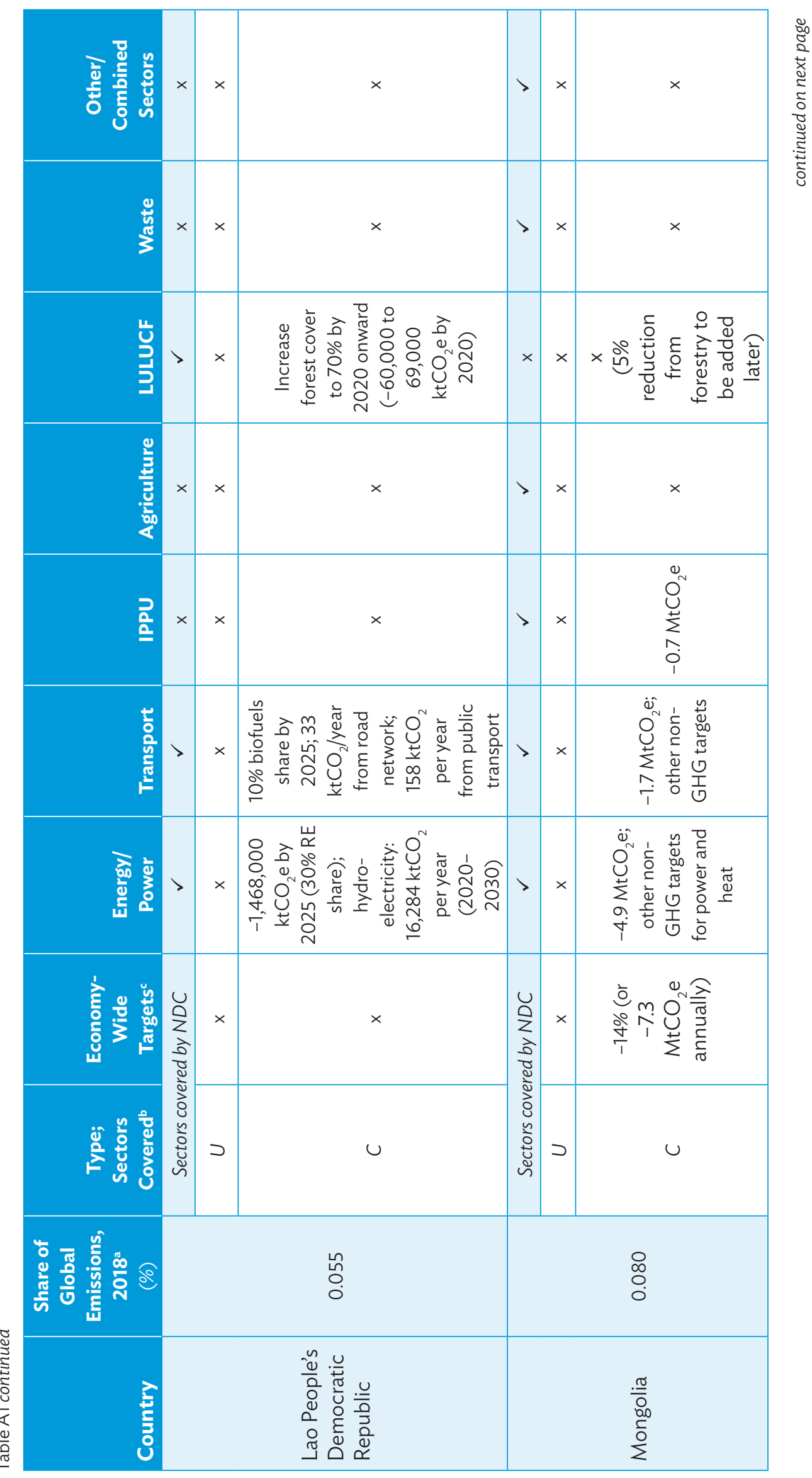




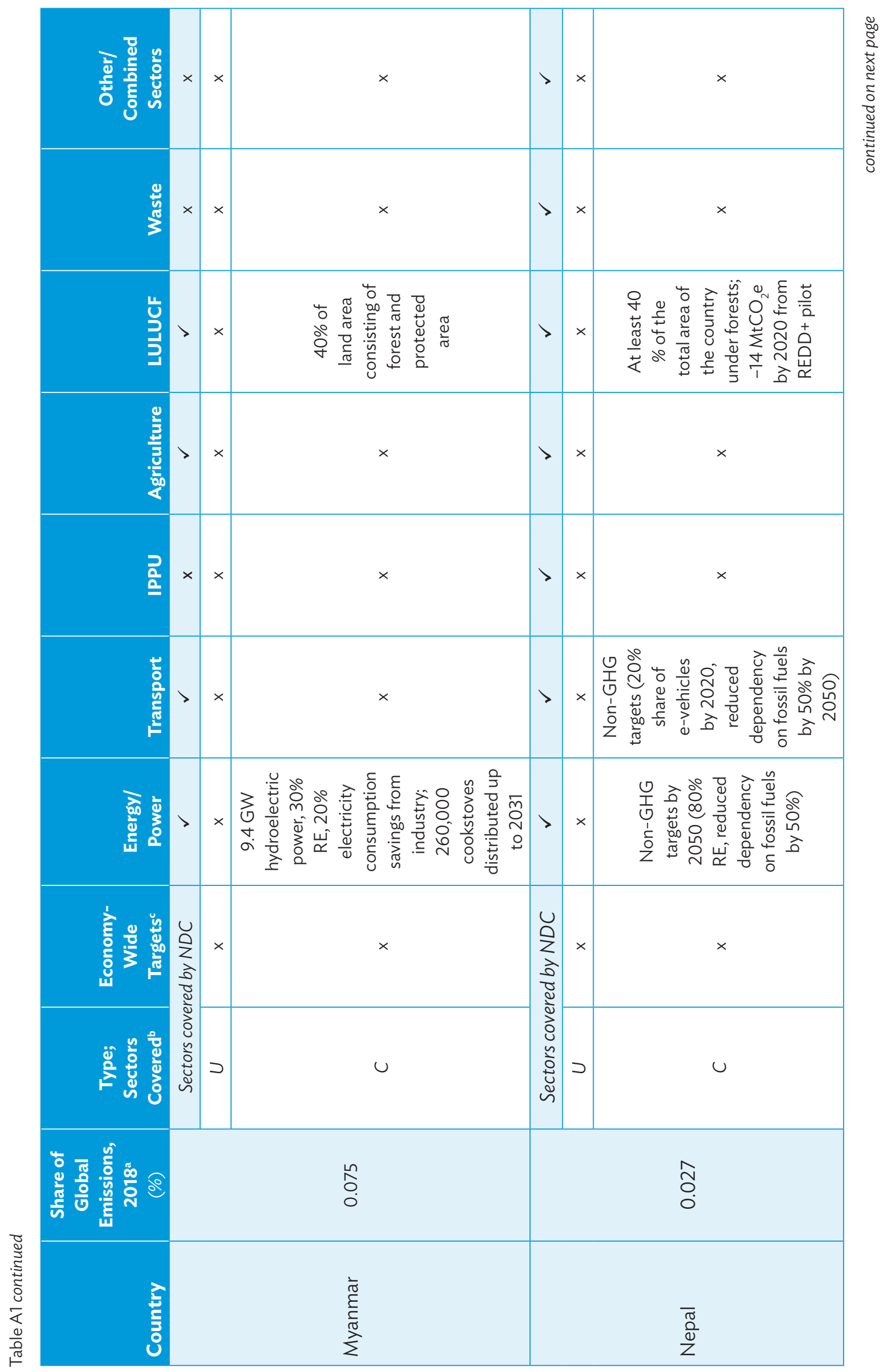




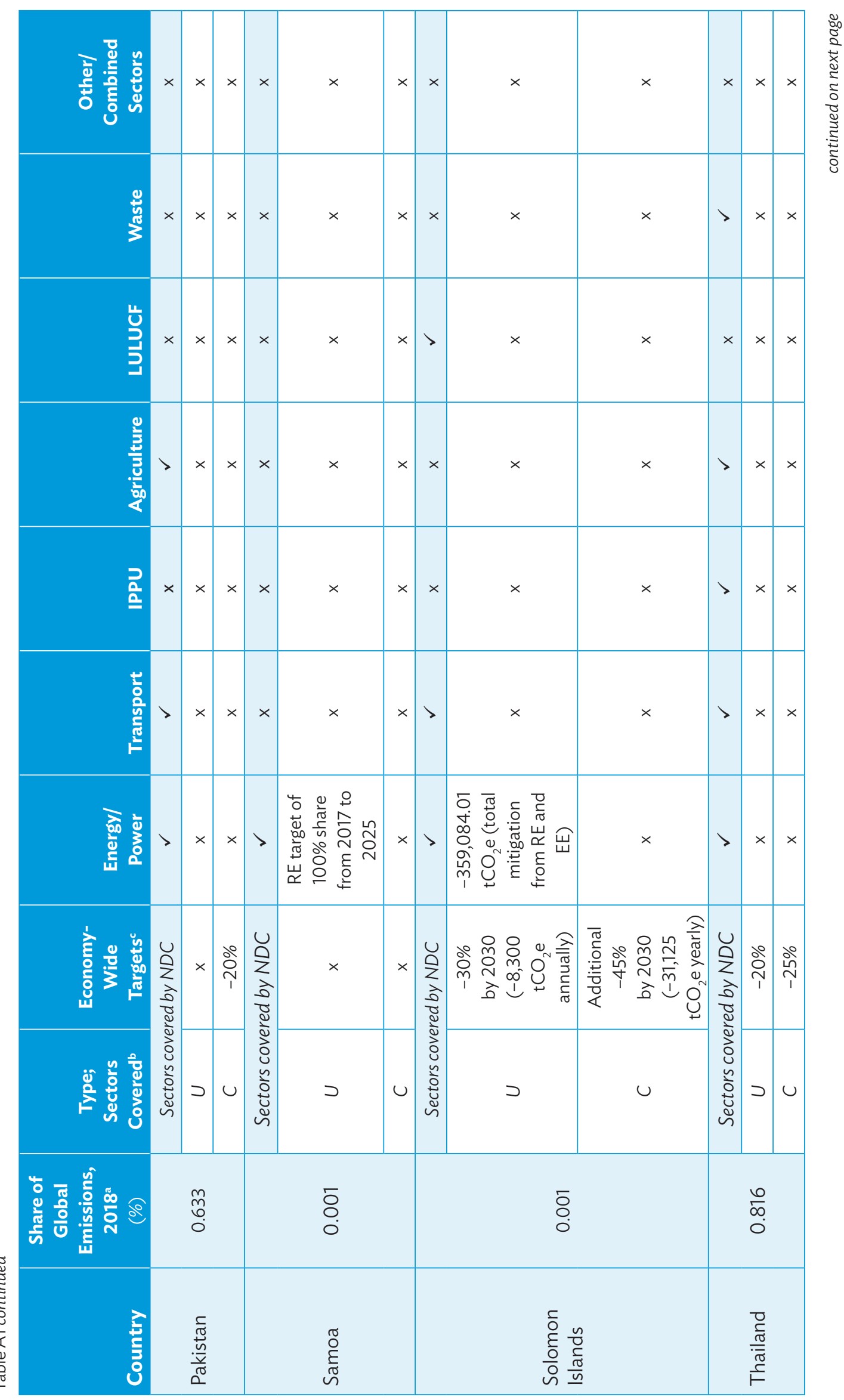




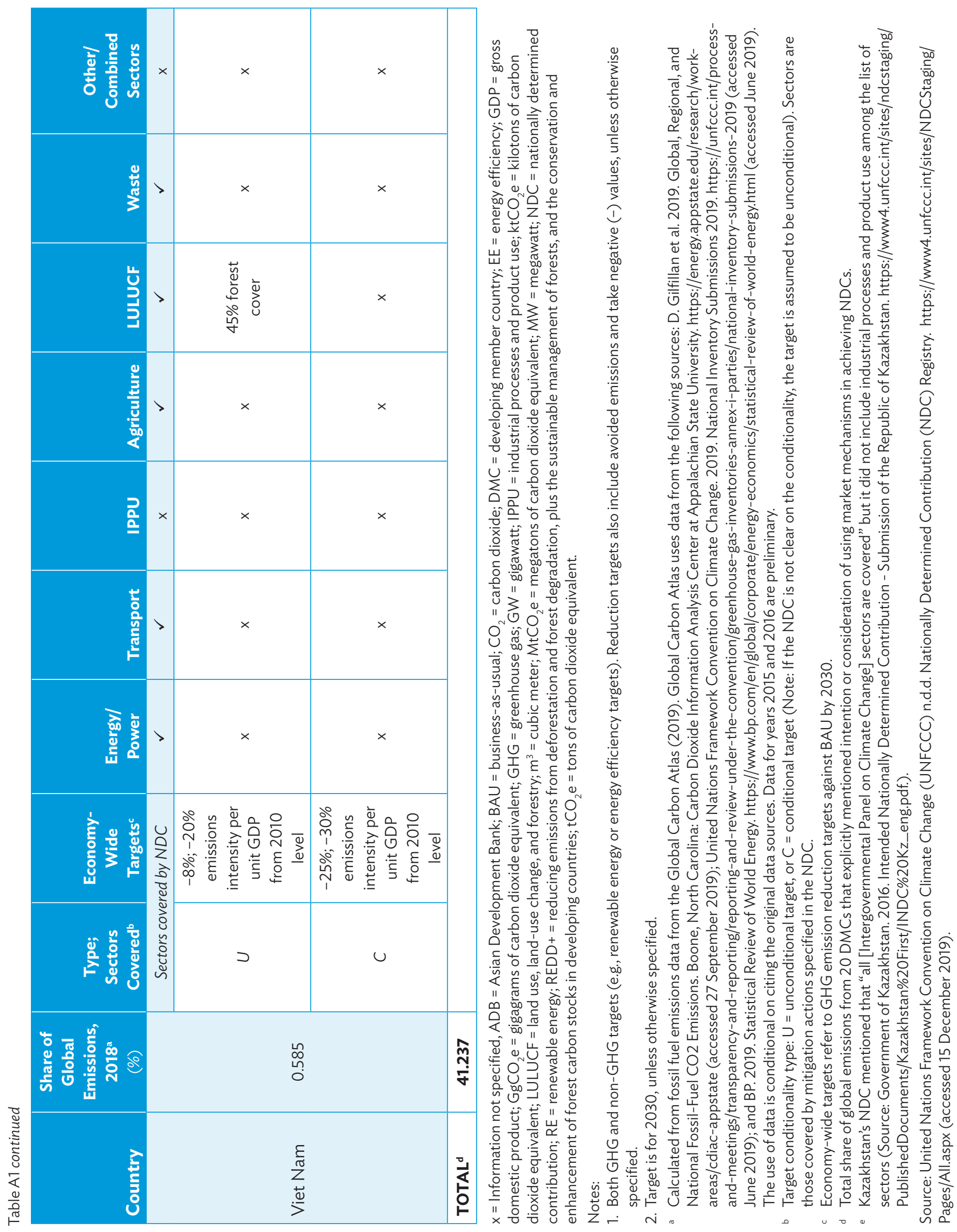




\section{Appendix 2: Overview of Emissions Trading Systems of ADB's Developing Members}

\section{Table A2: Emissions Trading Systems of ADB's Developing Members}

\begin{tabular}{|c|c|}
\hline DMCs & Overview of Emissions Trading System \\
\hline $\begin{array}{l}\text { China, } \\
\text { People's } \\
\text { Republic of }\end{array}$ & $\begin{array}{l}\text { Status: Launched regional ETS pilots in } 2013 \text { and announced the launch of national ETS in } \\
\text { December } 2017 . \\
\text { Coverage: The national ETS is expected to regulate around 1,700 companies from the power } \\
\text { sector. } \\
\text { Sector coverage: Initially power sector (including combined heat and power plants, and captive } \\
\text { power plants), and addition of seven sectors (petrochemicals, chemicals, building materials, } \\
\text { steel, nonferrous metals, paper, and domestic aviation). } \\
\text { Policy/Strategic framework: } \\
\text { - Notice on Key Works in Preparation for the Launch of the National ETS } \\
\text { - 13th Five-Year Work Plan for Greenhouse Gas Emission Control } \\
\text { - Work Plan for Construction of the National Emissions Trading System (Power Sector), } \\
\text { approved by the State Council in late } 2017 \\
\text { - Interim Administrative Measures on Emissions Trading } \\
\text { MRV: } \\
\text { - Guidelines on MRV were developed for } 24 \text { sectors in } 2013-2015 \text {. } \\
\text { - Verification guidelines for the eight sectors to be covered by the ETS is also available. } \\
\text { Link to other systems: Domestic (at the initial phase), but once the national ETS is fully } \\
\text { operational, linkage with other systems is possible. }\end{array}$ \\
\hline Indonesia & $\begin{array}{l}\text { Status: Considering an ETS as part of PMR since } 2017 . \\
\text { Sector coverage: Power and industry sector } \\
\text { Policy/Strategic framework: } \\
\text { - Act No. } 32 / 2009 \text { on Environmental Conservation and Management sets the legal basis for } \\
\text { environmental management and climate change policy in Indonesia. } \\
\text { - Government Regulation on Environmental Economic Instruments, passed in } 2017 \text {, sets the } \\
\text { basis for an emissions or waste permit trading system, to be implemented by } 2024 \text {. } \\
\text { MRV: } \\
\text { - Design and governance framework for an MRV system is in an advanced stage of } \\
\text { completion. } \\
\text { - MRV guidelines for the power sector were developed in mid-2018. } \\
\text { - A pilot MRV program for electricity generators was launched in late } 2018 \text {. } \\
\text { - Pilot MRV programs are being conducted in the cement and fertilizer sectors. }\end{array}$ \\
\hline \multirow{2}{*}{ Kazakhstan } & $\begin{array}{l}\text { Status: Launched an ETS in January 2013, suspended in 2016-2017, and resumed operations } \\
\text { on } 1 \text { January } 2018 . \\
\text { Sector coverage: Power and centralized heating, extractive industries (oil and gas mining), } \\
\text { and manufacturing (metallurgy, chemical and processing industries including the production of } \\
\text { cement, lime, gypsum, brick, and other building materials). }\end{array}$ \\
\hline & $\begin{array}{l}\text { Policy/Strategic framework: } \\
\text { - Environmental Code of the Republic of Kazakhstan } \\
\text { - National GHG Emission Quota Allocation Plan for 2018-2020 } \\
\text { - Rules for the allocation of quotas for GHG emissions and formation of reserves of the } \\
\text { established number and volume of quotas } \\
\text { - Rules for the trading of GHG emissions quota and carbon units }\end{array}$ \\
\hline
\end{tabular}


Table A2 continued

\begin{tabular}{|c|c|}
\hline DMCs & Overview of Emissions Trading System \\
\hline & $\begin{array}{l}\text { MRV: } \\
\text { - Businesses or financial facilities and operators of installations are required to submit annual } \\
\text { reports of } \mathrm{GHG} \text { emissions depending on their emission level. } \\
\text { - GHG emissions that need to be reported include: } \mathrm{CO}_{2} \text { emissions, methane, nitrous oxide, } \\
\text { and perfluorocarbon emissions. } \\
\text { - Emissions reports with their supporting data must be verified by accredited third parties. } \\
\text { - An online } \mathrm{MRV} \text { platform for } \mathrm{GHG} \text { emissions was launched in } 2018 \text {, which enabled emitters } \\
\text { to record their } \mathrm{GHG} \text { emissions and trade them online. } \\
\text { Link to other systems: The system allows domestic offsets. International credits may be } \\
\text { allowed in the future. }\end{array}$ \\
\hline Thailand & $\begin{array}{l}\text { Status: Considering a mandatory ETS, and is operating a voluntary ETS to test the registry and } \\
\text { trading platform. } \\
\text { A legal framework and a road map for ETS implementation are under development. } \\
\text { Policy/Strategic framework: } \\
\text { - The } 12 \text { th National Economic and Social Development Plan (2017-2021) } \\
\text { - The National Climate Change Master Plan (2015-2050) also refers to carbon markets as a } \\
\text { potential mechanism for reducing GHG emissions in the private sector. } \\
\text { MRV: } \\
\text { - MRV guidelines and systems for the Thailand V-ETS were developed in 2013-2016. }\end{array}$ \\
\hline Viet Nam & $\begin{array}{l}\text { Status: Considering an ETS for the steel sector and an MBI for the waste sector from } 2020 . \\
\text { Sector coverage: Steel and waste sectors } \\
\text { Policy/Strategic framework: } \\
\text { - Viet Nam's National Green Growth Strategy (2012) calls for the introduction of MBIs. } \\
\text { - A decree on a road map for GHG emissions, which references the use of carbon credits } \\
\text { and a carbon-pricing policy system, is set to be approved in } 2019 \text {. } \\
\text { - The Plan for Implementation of the Paris Agreement (PIPA), approved in 2016, includes } \\
\text { tasks related to development of carbon market in Viet Nam pursuant to Article } 6 \text { of the } \\
\text { Paris Agreement and priority mitigation initiatives including the improvement of national } \\
\text { GHG inventory. Carbon market tasks under PIPA lists piloting the application of market } \\
\text { instruments in industry, transport, agriculture, forestry, land-use and construction sector. } \\
\text { MRV: } \\
\text { - The planned MRV system and NAMA crediting will provide the experience that will } \\
\text { support the implementation of a sector-based cap-and-trade program in the steel sector. }\end{array}$ \\
\hline
\end{tabular}

$\mathrm{CO}_{2}=$ carbon dioxide, $\mathrm{DMC}=$ developing member country, $\mathrm{ETS}=$ emissions trading system, $\mathrm{GHG}$ = greenhouse gas, $\mathrm{MBI}=$ market based instrument, MRV = measurement, reporting, and verification, NAMA = nationally appropriate mitigation action, PMR = Partnership for Market Readiness, Thailand V-ETS = Thailand Voluntary Emissions Trading Scheme.

a World Bank. 2018a. Kazakhstan Launches Online Platform for Monitoring and Reporting Greenhouse Gases. https://www. worldbank.org/en/news/press-release/2018/02/05/kazakhstan-launched-online-platform-for-ghg-reporting.

b Government of Viet Nam. 2016. Plan for Implementation of the Paris Agreement. Hanoi. https://auschamvn.org/wp-content/ uploads/2016/10/Plan-for-implementation-of-Paris-Agreement-in-Vietnam-Eng.pdf.

Sources: International Carbon Action Partnership (ICAP). 2019b. Emissions Trading Worldwide: Status Report 2019. Berlin, Germany. https://icapcarbonaction.com/en/?option=com_attach\&task=download\&id=625; Partnership for Market Readiness (PMR). n.d. Implementing Country Participants. https://www.thepmr.org/pmrimplements/0. 


\section{Appendix 3: Experience with Project-Based Mechanisms of ADB's Developing Members}

Appendix 3 presents the number of projects under the Clean Development Mechanism (CDM) and the Joint Crediting Mechanism (JCM) hosted by ADB's developing member countries that are intending or considering to use market mechanisms to accomplish nationally determined contributions (NDCs).

Table A3: Clean Development Mechanism and Joint Crediting Mechanism Projects in Group 1 Countries

\begin{tabular}{|c|c|c|c|}
\hline \multirow[b]{2}{*}{ DMC } & $\mathrm{CDM}^{\mathrm{a}}$ & \multicolumn{2}{|c|}{ JCM } \\
\hline & Registered Projects & Registered Projects ${ }^{\mathrm{b}}$ & $\begin{array}{l}\text { Active Financed } \\
\text { Projects }^{c}\end{array}$ \\
\hline Afghanistan & 0 & - & - \\
\hline Armenia & 6 & - & - \\
\hline Bangladesh & 6 & 3 & 6 \\
\hline Bhutan & 5 & - & - \\
\hline Cambodia & 10 & 1 & 6 \\
\hline China, People's Republic of & 3,764 & - & - \\
\hline Fiji & 3 & - & - \\
\hline India & 1,669 & - & - \\
\hline Indonesia & 147 & 20 & 35 \\
\hline Kazakhstan & - & - & - \\
\hline Kiribati & - & - & - \\
\hline Lao PDR & 24 & 1 & 5 \\
\hline Mongolia & 4 & 5 & 9 \\
\hline Myanmar & 1 & 0 & 7 \\
\hline Nepal & 6 & - & - \\
\hline Pakistan & 37 & - & - \\
\hline Samoa & 0 & - & - \\
\hline Solomon Islands & 0 & - & - \\
\hline Thailand & 144 & 6 & 31 \\
\hline Viet Nam & 255 & 14 & 22 \\
\hline Total number of projects from Group 1 & 6,081 & 50 & 121 \\
\hline Total number of projects globally & 7,816 & 57 & 151 \\
\hline $\begin{array}{l}\text { Share of Group } 1 \text { countries from } \\
\text { total projects globally (\%) }\end{array}$ & 77.8 & 87.7 & 80.1 \\
\hline
\end{tabular}

$\mathrm{CDM}=$ Clean Development Mechanism, DMC = developing member country, JCM = Joint Crediting Mechanism, Lao PDR = Lao People's Democratic Republic, PRC = People's Republic of China.

Notes:

1. Under "CDM": (-) not in the list of "host countries" of CDM projects. Under "JCM": (-) not part of JCM partner countries with Japan.

2. Group 1 comprises 20 developing member countries of ADB that expressed their intent or consideration of using market mechanisms in their NDCs.

a United Nations Framework Convention on Climate Change (UNFCCC) 2020. CDM Project Activities. https://cdm.unfccc.int/ Statistics/Public/CDMinsights/index.html (accessed 4 February 2020).

b Joint Crediting Mechanism (JCM). Registered Projects. https://www.jcm.go.jp/projects/registers (accessed on 4 February 2020).

Institute for Global Environmental Strategies (IGES). 2019a. Joint Crediting Mechanism Database. 26 July. https://iges.or.jp/en/ pub/iges-joint-crediting-mechanism-jcm-database (accessed 4 February 2020).

Source: Asian Development Bank (Sustainable Development and Climate Change Department). 


\section{Appendix 4: Experience with Transparency and Reporting of Emission Reductions}

A country's interest and experience in using market mechanisms to achieve mitigation targets combined with its engagement in preparatory activities for post-2020 markets give a good indication of its readiness to participate in Article 6 mechanisms. However, another important consideration is how each country will implement activities based on the Paris Agreement's Enhanced Transparency Framework, as stipulated in Article 13. Whereas the guidance and rules for transparency and reporting of Article 6 activities are yet to be decided (United Nations Framework Convention on Climate Change [UNFCCC] 2019b), the transparency and reporting guidelines under the Enhanced Transparency Framework were adopted during the 24th Conference of the Parties to the UNFCCC (COP 24) as part of the Paris Agreement Rulebook (UNFCCC 2019d). Article 77(d) of these guidelines has controversial provisions, seen by some as prejudging the outcome of the Article 6 decision. Although they should not be taken as the final provisions of Article 6 relating to reporting, these provisions state that countries transferring mitigation outcomes should be able to report (i) "the annual level of anthropogenic emissions by sources and removals by sinks covered by the [nationally determined contribution] NDC on an annual basis reported biennially"; and provide (ii) "an emissions balance reflecting the level of anthropogenic emissions by sources and removals by sinks covered by their NDC, adjusted on the basis of 'corresponding adjustments' undertaken, by effecting an addition for internationally transferred mitigation outcomes (ITMOs) first-transferred/transferred and a subtraction for [ITMOs] used/acquired, consistent with decisions adopted by the [Conference of the Parties serving as the Meeting of the Parties to the Paris Agreement, or CMA] on Article 6" (UNFCCC 2019d).

These statements indicate that countries that plan to transfer mitigation outcomes under Article 6.2 will be required to establish a robust accounting and reporting system. Whether these provisions will apply to all countries with the intent to participate in international market mechanisms to accomplish NDCs is yet to be seen. In any case, the requirements for national inventories (at least for the sectors covered by the NDC) and monitoring, reporting, and verification (MRV) systems will be more advanced for the DMCs under Article 6 than the UNFCCC and Kyoto Protocol requirements.

Under the provisions of the UNFCCC, developed countries should submit national inventory reports (NIRs) every year and all Parties should submit national communications (NCs) every fourth year. In practice, developing countries have not been able to submit every fourth year-an experience shared by the countries in this study. Since 2014 (Cancún decision 2010), developed countries have been submitting biennial reports on their progress since their last NC, while developing countries submit biennial update reports (BURs) to update information in their last NC. Although both biennial reports and BURs should be submitted every 2 years, developing countries have had flexibility around this requirement. Under the Paris Agreement, all countries (except the least developed countries [LDCs] and small island developing states [SIDS]) are expected to submit reports and information every 2 years through Biennial Transparency Reports. LDCs and SIDS can submit reports whenever they can or want.

The Paris Agreement transparency decision elaborated in Katowice states that both developed and developing countries should report annual inventories after 2020: "Each Party shall report a consistent annual time series starting from 1990; those developing country Parties that need flexibility in light of their capacities with respect to this provision instead have the flexibility to report data covering, at a minimum, the reference year/period for its NDC under Article 4 of the Paris Agreement and, in addition, a consistent annual time series from at least 2020 onwards."

Among the Group 1 developing member countries (DMCs), or those countries that expressed in their NDCs their intent or consideration of using market mechanisms, only a few could match the 
abovementioned requirements, including the conduct of annual inventories, at their present capacities. The capacity and experience of DMCs in setting up and conducting MRV of their climate commitments and actions vary, and this may affect their ability to use international carbon market mechanisms. Table A4 gives an indication of DMCs' experience in MRV based on publicly available submissions of NCs, BURs, and NIRs, as well as available information on conducting additional annual greenhouse gas (GHG) inventories (in between official reporting years).

\section{Figure A4: Transparency and Reporting Experience of Group 1 Countries}

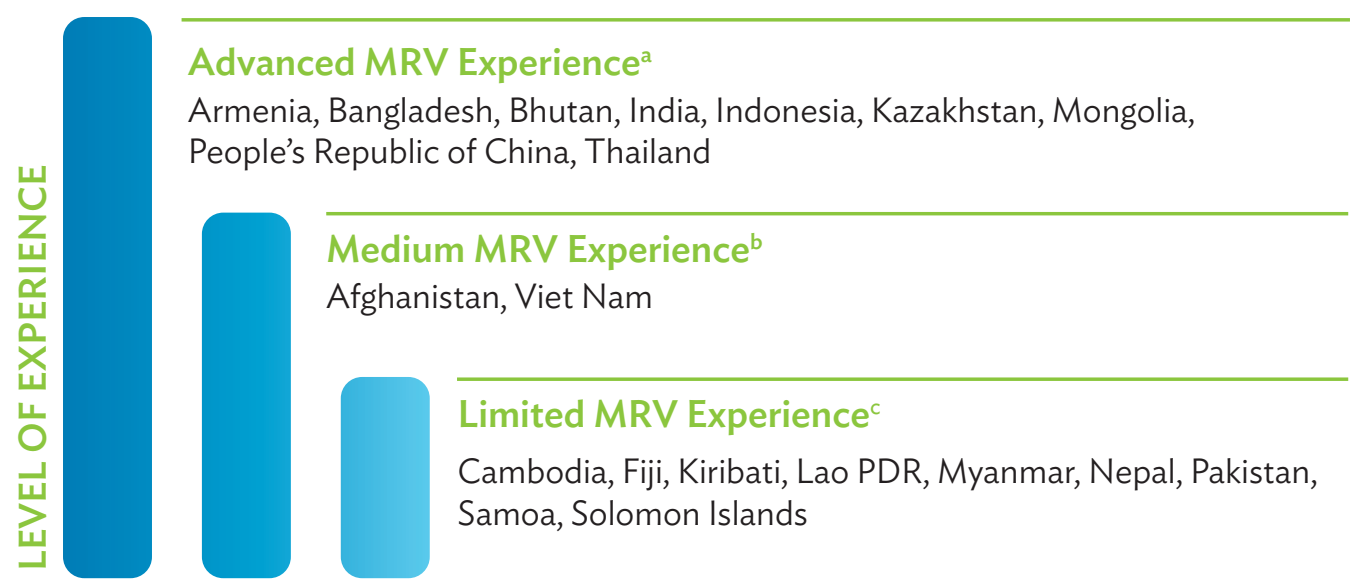

BUR = biennial update report; Lao PDR = Lao People's Democratic Republic; MRV = measurement, reporting, and verification; $\mathrm{NC}=$ national communication.

Note: Group 1 comprises 20 developing member countries of ADB that expressed their intent or consideration of using market mechanisms in their NDCs.

a Submitted NCs and BURs and conducted additional annual inventories.

b Submitted both NCs and BURs; no additional inventories.

c Submitted one to three NCs only; no BURs, no additional inventories.

Source: Asian Development Bank (Sustainable Development and Climate Change Department).

Regarding participation in Article 6, there could be specific requirements relating to the sectors covered by the NDC. Many countries have quantified sector emissions and emission reduction targets for their NDCs, while some have specified other non-GHG targets, particularly for energy subsectors (e.g., energy efficiency or renewable energy target). Appendix 1 shows DMCs that have quantified reduction targets per sector, entailing the establishment of more sophisticated MRV systems in order to report progress in each sector. Quantified mitigation targets can guide the design, planning, implementation, and tracking of mitigation measures, which can then lead to the development of better and more ambitious measures. 


\section{REFERENCES}

Amponin, J. A., and J. W. Evans. 2016. Assessing the Intended Nationally Determined Contributions of ADB Developing Members. Sustainable Development Working Papers Series. Manila: Asian Development Bank.

Asian Development Bank (ADB). 2015. Emissions Trading Schemes and Their Linking: Challenges and Opportunities in Asia and the Pacific. Manila. https://www.adb.org/sites/default/files/ publication/182501/emissions-trading-schemes.pdf.

ADB. 2016. Joint Crediting Mechanism: An Emerging Bilateral Crediting Mechanism. Manila. https://www.adb. org/documents/jcm-emerging-bilateral-crediting-mechanism.

_ 2018a. Article 6 of the Paris Agreement: Piloting for Enhanced Readiness. Manila. https://www.adb. org/publications/article-6-paris-agreement.

—. 2018b. Decoding Article 6 of the Paris Agreement. Manila. https://www.adb.org/publications/ decoding-article-6-paris-agreement.

—. 2019a. Article 6 of the Paris Agreement: Drawing Lessons from the Joint Crediting Mechanism. https://www.adb.org/publications/article-6-paris-agreement-lessons-jcm.

_. 2019b. Classification and Graduation of Developing Member Countries. Operations Manual. Section A1. 23 April. https://www.adb.org/sites/default/files/institutional-document/31483/om-a1.pdf.

_. 2019c. Negotiations on Article 6 of the Paris Agreement - Road to Madrid. https://www.adb.org/ publications/negotiations-article-6-paris-agreement.

Bajaj, K. 2018. Market-Based Approaches of the Paris Agreement: Where Are We Now? Discussion Papers Series. New Delhi, India: The Energy and Resources Institute (TERI).

Ecofys. 2017. NAMA Database Pipeline: October 2017. http://www.nama-database.org/index.php/ Special:RunQuery/QueryData (accessed 15 December 2019).

Environmental Defense Fund (EDF), CDC Climat Research, Caisse des Dépôts and International Emissions Trading Association (IETA). 2015. India: An Emissions Trading Case Study. https:// www.ieta.org/resources/Resources/Case_Studies_Worlds_Carbon_Markets/2015/india_ case_study_may2015.pdf.

European Union Reducing Emissions from Deforestation and Forest Degradation (REDD) Facility. 2014. Introduction to REDD+. http://www.euredd.efi.int/documents/15552/154912/ Introduction+to+REDD\%2B/eaabc68f-9176-40b0-acf3-dd4e81e40aad.

Forest Carbon Partnership Facility (FCPF) n.d. https://forestcarbonpartnership.org/.

Fuessler, J. et al. 2019. Article 6 in the Paris Agreement as an Ambition Mechanism: Options and Recommendations. Swedish Energy Agency.

Deutsche Gesellschaft für Internationale Zusammenarbeit (GIZ). n.d. Global Carbon Market. https:// www.giz.de/en/worldwide/42190.html.

GIZ and the Government of the People's Republic of China, Ministry of Ecology and Environment. n.d. ETS in China. https://ets-china.org/about-us/.

Global Carbon Atlas. 2019. CO Emissions. http://www.globalcarbonatlas.org/en/CO2-emissions (accessed 09 December 2019). [Data sources: (i) Boden, T. A., G. Marland, and R. J. Andres 2017. Global, Regional, and National Fossil-Fuel $\mathrm{CO}_{2}$ Emissions. Carbon Dioxide Information Analysis Center, Oak Ridge National Laboratory, US Department of Energy. DOI: 10.3334/ CDIAC/00001_V2017. http://cdiac.ess-dive.lbl.gov/trends/emis/meth_reg.html; (ii) United 
Nations Framework Convention on Climate Change (UNFCCC). 2017. National Inventory Submissions 2017. http://unfccc.int/national_reports/annex_i_ghg_inventories/national_ inventories_submissions/items/9492.php (accessed June 2017); (iii) BP. 2017. Statistical Review of World Energy. http://www.bp.com/en/global/corporate/energy-economics.html.]

Government of Indonesia, Directorate General for Climate Change Control. n.d. (Direktorat Jenderal Pengendalian Perubahan Iklim). ICER (Indonesia Certified Emission Reduction) - Mekanisme Sertifikasi Penurunan Emisi. In Bahasa. http://ditjenppi.menlhk.go.id/icer.html.

Government of the People's Republic of China, National Development and Reform Commission. 2017. Work Plan for Construction of the National Emissions Trading System (Power Sector). No. 2191. http://www.ndrc.gov.cn/zcfb/gfxwj/201712/W020171220566893899825.pdf. English translation: https://chinaenergyportal.org/en/national-carbon-emissions-trading-marketestablishment-program-power-generation-industry/.

Government of the Philippines, Senate. 2018. Legarda: Carbon Pricing Effective Measure to Achieve Mitigation Goals. Press release. 20 April. https://www.senate.gov.ph/press_release/2018/0420_ legarda1.asp.

Government of Viet Nam. 2016. Planfor Implementation of the Paris Agreement. Hanoi. https://auschamvn. org/wp-content/uploads/2016/10/Plan-for-implementation-of-Paris-Agreement-in-VietnamEng.pdf.

Greiner, S. et al. 2019. Moving Towards Next Generation Carbon Markets: Observations from Article 6 Pilots. March. https://www.climatefocus.com/publications/moving-towards-next-generation-carbonmarkets---observations-article-6-pilots.

Institute for Global Environmental Strategies (IGES). 2019a. Joint Crediting Mechanism Database. 26 July. https://iges.or.jp/en/pub/iges-joint-crediting-mechanism-jcm-database. (accessed 4 February 2020).

_. 2019b. Nationally Determined Contributions Database, version 7.1 (July 2019). https://pub.iges. or.jp/pub/iges-ndc-database (accessed 15 December 2019).

_. 2018. Summary for Policymakers. In V. Masson-Delmotte et al, eds. IPCC Special Report on Global Warming of $1.5^{\circ} \mathrm{C}$. https://www.ipcc.ch/sr15/.

International Carbon Action Partnership (ICAP). 2019a. Emissions Trading and Carbon Tax: Two Instruments, One Goal. ETS Brief. Berlin, Germany. https://icapcarbonaction.com/ en/?option=com_attach\&task=download\&id=638.

—. 2019b. Emissions Trading Worldwide: Status Report 2019. Berlin, Germany. https://icapcarbonaction. com/en/?option=com_attach\&task=download\&id=625.

2019c. ETS Detailed Information: China (Update as of 29 Oct 2019). https://icapcarbonaction. com/en/?option=com_etsmap\&task=export\&format=pdf\&layout=list\&systems[] $=55$.

_. 2019d.ETSDetailed Information:Indonesia(Updateas of 29Oct2019). https://icapcarbonaction. com/en/?option=com_etsmap\&task=export\&format=pdf\&layout=list\&systems[]=104.

- 2019e. ETS Detailed Information: Kazakhstan (Update as of 29 Oct 2019). https:// icapcarbonaction.com/en/?option=com_etsmap\&task=export\&format=pdf\&layout=list\&syste $\mathrm{ms} \% 5 \mathrm{~B} \% 5 \mathrm{D}=46$.

_.2019f. ETS Detailed Information: Thailand (Update as of 29 Oct 2019). https://icapcarbonaction. com/en/?option=com_etsmap\&task=export\&format=pdf\&layout=list\&systems $[=81$.

2019g. ETS Detailed Information: Vietnam (Update as of 29 Oct 2019). https://icapcarbonaction. com/en/?option=com_etsmap\&task=export\&format=pdf\&layout=list\&systems\%5B\%5D=83. 
Joint Crediting Mechanism (JCM). n.d. Registered Projects. https://www.jcm.go.jp/projects/registers (accessed on 4 February 2020).

La Hoz Theuer, S. et al. 2017. International Transfers under Article 6 in the Context of Diverse Ambition of NDCs. SEI Working Papers Series. Stockholm, Sweden: Stockholm Environment Institute.

Magalang, A. A. 2018. The Role of Article 6 in the Context of the Philippines' NDC. Presentation at the 24th Conference of the Parties to the United Nations Framework Convention on Climate Change (COP24). Katowice, Poland. 3-18 December. https://www.ieta.org/resources/COP24/Misc\%20 Media\%20Files/Dec7/SE20.pdf.

Michaelowa, A. et al. 2018. Opportunities for Carbon Pricing in Viet Nam. USAID, Viet Nam Ministry of Planning and Investment, Viet Nam Ministry of Finance, and United Nations Development Programme.

NAMA Facility. n.d. Projects. https://www.nama-facility.org/projects/?tx_news_pi1[overwriteDemand] [categories]=13,„\&no_cache=1 (accessed 15 December 2019).

Nordic Initiative for Cooperative Approaches (NICA). 2019. Landscape of Article 6 Pilots: A Closer Look at Initial Cooperative Approaches. Nordic Environment Finance Corporation (NEFCO), Ministry for Foreign Affairs of Finland, Norwegian Ministry of Climate and Environment, and Swedish Energy Agency. https://www.nefco.org/wp-content/uploads/2019/05/NICA-Article-6-mapppingstudy-April-2019.pdf.

Okubo, Y., D. Hayashi, and A. Michaelowa. 2011. NAMA Crediting: How to Assess Offsets from and Additionality of Policy-Based Mitigation Actions in Developing Countries. Greenhouse Gas Measurement and Management. 1 (1). pp. 37-46. https://DOI.org/10.3763/ghgmm.2010.0002.

Organisation for Economic Co-operation and Development (OECD). 2018. Supplement to Effective Carbon Rates: People's Republic of China. https://www.oecd.org/tax/tax-policy/effective-carbonrates-china.pdf.

Pachauri, R. K. and L. A. Meyer, eds. 2014. Climate Change 2014: Synthesis Report. Contribution of Working Groups I, II and III to the Fifth Assessment Report. Geneva, Switzerland: Intergovernmental Panel on Climate Change (IPCC).

Partnership for Market Readiness (PMR). 2015. Thailand Voluntary Emission Reduction Program (T-VER). Presentation by the Thailand Greenhouse Gas Management Organization https:// www.thepmr.org/system/files/documents/Eng\%2025580930\%20TVER\%20mechanism.pdf.

—. 2019a. Annual Report 2019: From Readiness to Implementation. https://www.thepmr.org/sites/ wbpmr/files/PMR_Annual\%20Report.2019_0.pdf.

—. 2019b. Indonesia Certified Emission Reduction Mechanism (ICER). http://www.pmr-indonesia. org/en/sosialisasi-dan-konsultasi-publik-mekanisme-icer/. 15 April.

—. 2019c. Indonesia. Project Implementation Status Report. https://www.thepmr.org/system/files/ documents/Indonesia\%20PMR\%20Project\%20Implementation\%20Status\%20Report\%20 2019.pdf.

—. 2019d. Partnership for Market Implementation. https://www.worldbank.org/en/topic/ climatechange/brief/partnership-for-market-implementation.

- 2019e. PMR Country Support Program. Presentation by J. Ramirez of the PMR Secretariat at the 20th PMR Partnership Assembly Meeting. Brussels, Belgium. 29-30 May.

2019f. PMR Project Implementation Status Report (ISR). Philippines. April. https://www.thepmr.org/ system/files/documents/2019\%20Philippines\%20PMR\%20Project\%20Implementation\%20 Status\%20Report.pdf. 
_. n.d. Implementing Country Participants. https://www.thepmr.org/pmrimplements/0.

Perspectives Climate Group. 2019. Transition Pathways for the Clean Development Mechanism under Article 6 of the Paris Agreement: Options and Implications for International Negotiators. Freiburg, Germany. https://www.perspectives.cc/fileadmin/user_upload/Transition_pathways_for_the_ CDM_2019.pdf.

Reis, L. A. et al. 2016. The Economics of Greenhouse Gas Mitigation in Developing Asia. Economics Working Papers Series. Manila: Asian Development Bank. https://www.adb.org/sites/default/files/ publication/218871/ewp-504.pdf.

Solar Impulse Foundation. Paris Agreement: Solutions to Tackle Climate Change. https://solarimpulse.com/ paris-agreement?gclid=EAlalQobChMInfzO4Nr_5AIVD6qWCh3GvwIWEAAYASAAEglp7 vD_BwE.

Spalding-Fecher, R. 2018. Building a Pipeline for Scaled-up Crediting: Lessons Learned from the Solid Waste Management Sector in a Developing Country. Carbon Limits.

Strand, Jon. 2017. Unconditional and Conditional NDCs under the Paris Agreement: Interpretations and Their Relations to Policy Instruments. Working Paper 09/2017. Oslo Centre for Research on Environmentally friendly Energy (CREE); Centres for Environment-friendly Energy Research (CEER), Norway; Frisch Centre, Norway; Statistics Norway; Department of Economics, University of Oslo; and Tilburg Sustainability Center, Netherlands.

Thailand Greenhouse Gas Management Organization (TGO). 2014. Thailand Voluntary Emission Reduction Program (T-VER) http://conference.tgo.or.th/download/tgo_or_th/seminar/ presentation/2014/Mar/2728/06_TVER.pdf.

—. n.d. Thailand Voluntary Emission Reduction Program (in Thai). http://carbonmarket.tgo.or.th/ cco/cco.pnc.

Transformative Carbon Asset Facility (TCAF). n.d. https://tcaf.worldbank.org/about-us.

United Nations Collaborative Programme on Reducing Emissions from Deforestation and Forest Degradation (UN-REDD). About REDD+. https://www.unredd.net/about/what-is-redd-plus. html.

United Nations Environment Programme (UNEP). 2019. Emissions Gap Report 2019. Nairobi, Kenya.

United Nations Environment Programme (UNEP) and Technical University of Denmark (DTU) Partnership-Centre on Energy, Climate, and Sustainable Development. 2019. CDM projects by host region. Last updated 1 December 2019. http://www.cdmpipeline.org/cdm-projects-region. htm.

United Nations Framework Convention on Climate Change (UNFCCC). 2008. Report of the Conference of the Parties on its thirteenth session, held in Bali from 3 to 15 December 2007. Addendum Part Two: Action taken by the Conference of the Parties at its thirteenth session. FCCC/CP/2007/6/Add.1.

2. 2016. How Nationally Appropriate Mitigation Actions Can Be Effectively Used as Building Blocks for the Implementation of Countries' Nationally Determined Contributions under the Paris Agreement. https://unfccc.int/sites/default/files/addis-ws-report.pdf.

2019a. National Inventory Submissions 2019. https:/unfccc.int/process-and-meetings/ transparency-and-reporting/reporting-and-review-under-the-convention/greenhouse-gasinventories-annex-i-parties/national-inventory-submissions-2019 (accessed 15 December 2019).

2019b. Publication of Study on Cooperative MRV as a Foundation for a Potential Regional Carbon Market within ASEAN. https://unfccc.int/page/publication-of-study-on-cooperativemrv-as-a-foundation-for-a-potential-regional-carbon-market. 
2019c. Report of the Conference of the Parties serving as the meeting of the Parties to the Paris Agreement on the third part of its first session, held in Katowice from 2 to 15 December 2018. Addendum 1. FCCC/PA/CMA/2018/3/Add.1, Decision 8/CMA.1.

. 2019d. Report of the Conference of the Parties serving as the meeting of the Parties to the Paris Agreement on the third part of its first session, held in Katowice from 2 to 15 December 2018. Addendum 2. FCCC/PA/CMA/2018/3/Add.2, Decision 18/CMA.1.

- n.d.a. About Carbon Pricing. https://unfccc.int/about-us/regional-collaboration-centres/the-ciaca-initiative/about-carbon-pricing.

- n.d.c. Nationally Appropriate Mitigation Actions (NAMAs). https://unfccc.int/topics/mitigation/ workstreams/nationally-appropriate-mitigation-actions.

—. n.d.d. Nationally Determined Contribution (NDC) Registry. https://www4.unfccc.int/sites/ NDCStaging/Pages/All.aspx (accessed 15 December 2019).

—. n.d.f. The Collaborative Instruments for Ambitious Climate Action (Cl-ACA) Initiative. https:// unfccc.int/about-us/regional-collaboration-centres/the-collaborative-instruments-forambitious-climate-action-ci-aca-initiative.

—. n.d.g. What is the clean development mechanism? https://cdm.unfccc.int/about/index.html.

_. 2020. CDM Project Activities. https://cdm.unfccc.int/Statistics/Public/CDMinsights/index.html (accessed 4 February 2020).

United Nations Treaty Collection. 2019. CHAPTER XXVII ENVIRONMENT 7. D Paris Agreement. https://treaties.un.org/Pages/ViewDetails.aspx?src=TREATY\&mtdsg_no=XXVII-7d\&chapter=27\&clang=_en. (accessed 15 December 2019)

World Bank. 2018. Carbon Markets under the Kyoto Protocol: Lessons Learned for Building an International Carbon Market under the Paris Agreement. World Bank Working Paper. Washington, DC.

_. 2018a. Kazakhstan Launches Online Platform for Monitoring and Reporting Greenhouse Gases. https://www.worldbank.org/en/news/press-release/2018/02/05/kazakhstan-launched-onlineplatform-for-ghg-reporting.

—. 2018b. Concept Note: Bhutan Climate Fund (June 2018). http://documents.worldbank.org/ curated/en/971531538568130794/pdf/Bhutan-Climate-Fund-Concept-Note.pdf.

2019a. Climate Finance and Initiatives. https://www.worldbank.org/en/topic/climatechange/ brief/world-bank-carbon-funds-facilities.

2019b. World Bank presentation on "Creating Climate Markets: Operationalizing Article 6" during the "Informal Forum on Implementation of Article 6 of the Paris Agreement under the UNFCCC process" organized by the European Roundtable on Climate Change and Sustainable Transition on 5-6 March 2019 at Glion, Switzerland. https://ercst.org/wp-content/uploads/2019/02/ World-Bank-Article-6-pilots.pdf.

2019c. Lao PDR Clean Cook Stove Initiative (P169538). Project Information Document. http://documents.worldbank.org/curated/en/380611550108853118/pdf/Concept-ProjectInformation-Document-PID-Lao-PDR-Clean-Cook-Stove-Initiative-P169538.pdf.

_. 2019d. State and Trends of Carbon Pricing 2019. Washington, DC. http://documents.worldbank. org/curated/en/191801559846379845/State-and-Trends-of-Carbon-Pricing-2019.

—. n.d. Carbon Pricing Dashboard. https://carbonpricingdashboard.worldbank.org/what-carbonpricing. 


\section{Nationally Determined Contributions}

Government of Afghanistan. 2015. Intended Nationally Determined Contribution: Submission to the United Nations Framework Convention on Climate Change. https://www4.unfccc.int/sites/ ndcstaging/PublishedDocuments/Afghanistan\%20First/INDC_AFG_20150927_FINAL.pdf.

Government of Armenia. 2015. Intended Nationally Determined Contribution of the Republic of Armenia under the UN Climate Change Framework Convention. https://www4.unfccc.int/sites/ ndcstaging/PublishedDocuments/Armenia\%20First/INDC-Armenia.pdf.

Government of Bangladesh. 2015. Intended Nationally Determined Contributions (INDC). https:// www4.unfccc.int/sites/ndcstaging/PublishedDocuments/Bangladesh\%20First/INDC_2015_ of_Bangladesh.pdf.

Government of Bhutan. 2015. Kingdom of Bhutan: Intended Nationally Determined Contribution. https://www4.unfccc.int/sites/ndcstaging/PublishedDocuments/Bhutan\%20First/BhutanINDC-20150930.pdf.

Government of Cambodia. 2017. Cambodia's Intended Nationally Determined Contribution. https://www4.unfccc.int/sites/ndcstaging/PublishedDocuments/Cambodia\%20First/ Cambodia\%27s\%20INDC\%20to\%20the\%20UNFCCC.pdf.

Government of Fiji. 2016. Fiji's Intended Nationally Determined Contribution. https://www4.unfccc.int/ sites/ndcstaging/PublishedDocuments/Fiji\%20First/FIJI_iNDC_Final_051115.pdf.

Government of India. 2016. India's Intended Nationally Determined Contribution: Working Towards Climate Justice. https://www4.unfccc.int/sites/ndcstaging/PublishedDocuments/India\%20 First/INDIA\%20INDC\%20TO\%20UNFCCC.pdf.

Government of Indonesia. 2016. First Nationally Determined Contribution, Republic of Indonesia. https://www4.unfccc.int/sites/ndcstaging/PublishedDocuments/Indonesia\%20First/First\%20 NDC\%20Indonesia_submitted\%20to\%20UNFCCC\%20Set_November\%20\%202016.pdf.

Government of Kazakhstan. 2016. Intended Nationally Determined Contribution - Submission of the Republic of Kazakhstan. https://www4.unfccc.int/sites/ndcstaging/PublishedDocuments/ Kazakhstan\%20First/INDC\%20Kz_eng.pdf.

Government of Kiribati. 2016. Intended Nationally Determined Contribution. https://www4.unfccc.int/ sites/ndcstaging/PublishedDocuments/Kiribati\%20First/INDC_KIRIBATI.pdf.

Government of the Lao People's Democratic Republic. 2015. Intended Nationally Determined Contribution. https://www4.unfccc.int/sites/ndcstaging/PublishedDocuments/Lao\%20People\%27s\%20 Democratic\%20Republic\%20First/Lao\%20PDR\%20First\%20NDC.pdf.

Government of Mongolia. 2016. Intended Nationally Determined Contribution (INDC) Submission by Mongolia to the Ad-Hoc Working Group on the Durban Platform for Enhanced Action (ADP). https://www4.unfccc.int/sites/ndcstaging/PublishedDocuments/Mongolia\%20First/150924_ INDCs\%20of\%20Mongolia.pdf.

Government of Myanmar. 2016. Myanmar's Intended Nationally Determined Contribution-INDC. https://www4.unfccc.int/sites/ndcstaging/PublishedDocuments/Myanmar\%20First/ Myanmar\%27s\%20INDC.pdf.

Government of Nepal. 2016. Nationally Determined Contributions. https://www4.unfccc.int/sites/ ndcstaging/PublishedDocuments/Nepal\%20First/Nepal\%20First\%20NDC.pdf.

Government of Pakistan. 2016. Pakistan's Intended Nationally Determined Contribution (PAK-INDC). https://www4.unfccc.int/sites/ndcstaging/PublishedDocuments/Pakistan\%20First/Pak-INDC.pdf. 
Government of the People's Republic of China. 2015. Enhanced Actions on Climate Change: China's Intended Nationally Determined Contributions. https://www4.unfccc.int/sites/ndcstaging/ PublishedDocuments/China\%20First/China\%27s\%20First\%20NDC\%20Submission.pdf.

Government of Samoa. 2016. Samoa's Intended Nationally Determined Contributions. https:// www4.unfccc.int/sites/ndcstaging/PublishedDocuments/Samoa\%20First/Samoa\%20INDC_ Submission\%20to\%20UNFCCC.pdf.

Government of Solomon Islands. 2016. Intended Nationally Determined Contribution. https:// www4.unfccc.int/sites/ndcstaging/PublishedDocuments/Solomon\%20lslands\%20First/ SOLOMON\%20ISLANDS\%20INDC.pdf.

Government of Thailand. 2015. Submission by Thailand: Intended Nationally Determined Contribution and Relevant Information. https://www4.unfccc.int/sites/ndcstaging/PublishedDocuments/ Thailand\%20First/Thailand_INDC.pdf.

Government of Viet Nam. 2016. Intended Nationally Determined Contribution of Viet Nam. https://www4.unfccc.int/sites/ndcstaging/PublishedDocuments/Viet\%20Nam\%20First/ VIETNAM\%27S\%20INDC.pdf. 


\section{Achieving Nationally Determined Contributions through Market Mechanisms in Asia and the Pacific}

Nationally determined contributions (NDCs) are at the heart of the Paris Agreement. They outline the climate change adaptation and mitigation commitments of countries. This working paper analyzes NDCs of developing member countries (DMCs) of the Asian Development Bank. It focuses on the context of the intent and preparedness of DMCs to use market mechanisms in achieving targets set out in their NDCs and potentially raising ambition over time. The paper also assesses 20 out of 41 DMCs in Asia and the Pacific that have expressed intent to use market mechanisms in their NDCs -in terms of their experience and preparedness for accessing new carbon markets under Article 6 of the Paris Agreement.

\section{About the Asian Development Bank}

ADB is committed to achieving a prosperous, inclusive, resilient, and sustainable Asia and the Pacific, while sustaining its efforts to eradicate extreme poverty. Established in 1966, it is owned by 68 members -49 from the region. Its main instruments for helping its developing member countries are policy dialogue, loans, equity investments, guarantees, grants, and technical assistance. 